\title{
ILO’nun Çalışma Yaşamının Geleceği Öngörüsünde Niteliği Değişen Dış Kaynak Kullanımının Rolü: İstihdam ve Ücret İlişkileri Açısından Bir Değerlendirme
}

\section{The Changing Role of Outsourcing In ILO's Future of Work Initiative: An Evalution In Terms of Employment and Wage Relations}

\author{
Ali İhsan Çelen' ${ }^{10}$
}

\section{Öz}

Tarihsel gelişim sürecinde olduğu gibi günümüzde de dış kaynak kullanımı, çalışma hayatını şekillendiren faktörlerin başında gelmektedir. Buna göre çalışmanın amacını; ILO'nun çalışma yaşamının geleceği öngörüsünde niteliği değişen dış kaynak kullanımının rolünü istihdam ve ücret ilişkileri açısından incelemek oluşturmaktadır. Bu kapsamda yöntem olarak ILO'nun çalışma yaşamının geleceği öngörüsü ile ilgili raporları incelenmiş ve ILO'nun belirlediği çalışma yaşamının geçeğini şekillendiren temel faktörler çerçevesinde dış kaynak kullanımının değişen niteliği değerlendirilmiştir. Sonuç olarak ILO'nun çalışma yaşamının geleceğini şekillendireceğini öngördüğü temel faktörler, aynı zamanda dış kaynak kullanımının niteliğini de değiştirmektedir. Bu faktörler; teknoloji ve bilgi tabanlı ekonomi, küreselleşme ve sanayisizleşme, eşitsizlik ve sosyal koruma, demografi ve çevre faktörleridir. Dış kaynak kullanımının niteliğini değiştiren en önemli faktör ise teknoloji ve bilgi tabanlı ekonomide yaşanılan gelişmelerdir. Öngörülen bu faktörler istihdam ilişkilerini; dinamik ve esnek istihdam çerçevesinde vasıflı işgücü talebinin hızla arttırması, işgücü piyasalarının küreselleştirmesi, dışa yatııı ve hizmet sektörünün ağırlık kazanması, kutuplaşma sorunu, sosyal koruma ihtiyacının artması, yaşlı ve çocuk bakımında göçmen istihdamı, iklim değişikliğine bağlı olarak yeşillenmeye bırakılan sektörlerin önem kazanması çerçevesinde etkilemektedir. Ücret ilişkilerinde ise en önemli etki, ücret eşitsizliklerinin yaygınlaşması noktasında görülmektedir. Buna göre ILO’nun dış kaynak kullanımının değişen niteliğine ayrıca önem vermesi, küresel işgücü piyasalarının geleceğinin anlaşıması açısından büyük önem taşımaktadır.

\section{Anahtar Kelimeler}

ILO, Çalışma yaşamının geleceği girişimi, Dış kaynak kullanımı

\footnotetext{
1 Sorumlu Yazar: Ali İhsan Çelen (Öğr. Gör. Dr.), Ordu Üniversitesi, Ünye Meslek Yüksekokulu, Yönetim ve Organizasyon Bölümü, İnsan Kaynakları Yönetimi Programı. E-posta: aliihsancelen@gmail.com ORCID: 0000-0002-8009-3432

Atıf: Celen, A. I. (2019). ILO’nun çalışma yaşamının geleceği öngörüsünde niteliği değişen dış kaynak kullanımının rolü: istihdam ve ücret ilişkileri açısından bir değerlendirme. Sosyal Siyaset Konferansları Dergisi, 77: $201-234$. https://doi.org/10.26650/jspc.2019.77.0016
} 


\begin{abstract}
As in the process of historical development, outsourcing is one of the main factors shaping working life today. Accordingly, the purpose of this study is to examine the role of ILO's changing outsourcing in predicting the future of working life in terms of employment and wage relations. In this context, the reports of ILO on the prediction of the future of working life were examined and the changing nature of outsourcing was evaluated within the framework of the basic factors shaping the reality of working life determined by ILO. As a result, the main factors that ILO predicts will shape the future of working life also change the quality of outsourcing. These factors are technology and knowledge-based economy, globalization and deindustrialization, inequality and social protection, demography and environmental factors. The most important factor that changes the quality of outsourcing is developments in technology and knowledge based economy.These predicted factors include employment relations, rapidly increasing the demand for skilled labor within the framework of dynamic and flexible employment, globalization of labor markets, gaining weight in foreign investment and service sector, polarization of problems, increasing the need for social protection, migrant employment in the elderly and child care, and the importance of sectors involved in environmental issues due to climate change. In wage relations, the most important effect is seen in the spread of wage inequalities. Accordingly, ILO's emphasis on the changing nature of outsourcing is crucial for understanding the future of global labor markets.
\end{abstract}

\title{
Keywords
}

ILO, Future of work initiative, Outsourcing

\section{Extended Summary}

The 102nd session of the ILO laid the foundation for the next century's initiative for the future of working life. In this session, the main factors that transform working life were first determined and these were demography, environment, technology, poverty, inequality, international balance, production and employment. The future of work initiative is more inclusive than the other suggested initiative, it has a longer duration and more universal. Also it has a very modern feature according to Millenium Development Goals (MDG) and Sustainable Development Goals

The research period covers the years 2016, 2017, 2018 and 2019. Accordingly, it was planned that the national dialogue mechanism in 2016 about work and society, decent work, work and production organization and governance of work subjects. A global commission was established in 2017 in the light of the data obtained from the member countries. In 2018, a commission report was prepared and the declaration of the century was foreseen to be adopted in 2019. In the commission report issued in 2018, the main factors predicted to lead the future of working life were identified. These factors are technological change and knowledge-based economy, globalization and deindustrialization, the effects 
of business restructuring on inequality and social protection, demographic and environmental factors. Within the scope of technological and knowledge based economy, more investment in knowledge-based economy, on-line platforms, information technologies and digital work platforms stand out. Within the scope of globalization and deindustrialization, global supply chains, flexibility in the production process, profit-orientedness, investment in other countries, expansion of the service sector are influential factors. The problem of inequality due to the restructuring of the work and the need for more social protection as a result of each passing day is gaining importance. Morover, both in the context of demographic developments the problem of aging population is experienced and due to changing population profiles, the differentiation of social needs becomes important. On the one hand, due to the increasing climate and environmental problems, the green economy is gaining importance. In this context, green manufacturing becomes important.

On the other hand, as in the historical development process, outsourcing is an important aspect of production systems. In this respect, outsourcing affects working relationships. The use of outsourcing has been carried to a different dimension through the globalization process. The outsourcing of administrative affairs in the 90s has also undergone a significant transformation process since the mid-90s with a series of economic crises in developing countries and rapid technological developments since the early 2000s.

In addition, the main factor that ILO predicts will lead the future of working life is a change in the quality of outsourcing. Accordingly, as technological change increases, investment in the knowledge-based economy increases. And outsourcing for businesses is becoming even more attractive. Time constraints, rapid digitalization, information technologies, artificial intelligence, vulnerability, intelligent automation technologies, new distribution models, virtualization etc. play an active role in this process. Furthermore, the popularization of outsourcing due to globalization and industrialization raises issues such as creative destruction, polarization, increasing inequality, social insecurity and so on. Likewise, increasing demand for skilled labour makes it vital to solve problems in the education system. On the other hand within the scope of demographic developments; provision for the elderly and child care in day care institutions or nursing homes, employment of legal or illegal immigrants in this sector, provision of surrogacy services have become important issues. In 
addition, the transition green economy policies have gained importance on climate change and environmental issues.

Accordingly, the changing nature of outsourcing is influenced by key factors that ILO predicts will shape the future of working life. In this respect, outsourcing plays an important role in shaping working life and will continue to do so. The effect of this change process on employment relations can be predicted to be seen in the following issues: Independent work, more requirements for labor employment, gaining skills before they are needed, networks, ecosystems, rapid transition to skills and competencies, mercenary intellectuals, global human resources, more flexible and more individual employment relations, more mobile labor market, need more time on self-improvement, just in time learning and so on. Moreover, considering that developments in technology and knowledge based economy are more effective in this process, changing business relations generally in favor of skilled labor can lead to important problems regarding wage inequalities.

As a result, the changing nature of outsourcing in the future of working life can be predicted to play a leading role in the deepening of existing problems and the emergence of new problems. In this process, the problems that can be seen in wage and employment relations are at the forefront. The ILO has implemented the mechanism of social dialogue as an important process in the future of working life initiative. For this reason, the mechanism of social dialogue is an important way to solve the problems that are experienced and may be experienced. Also, ILO's assessment of the changing nature of outsourcing is of great importance for understanding the future of global labor markets. 


\section{ILO'nun Çalışma Yaşamının Geleceği Öngörüsünde Niteliği Değişen Dış Kaynak Kullanımının Rolü: İstihdam ve Ücret İlişkileri Açısından Bir Değerlendirme}

\section{Çalışma Yaşamının Geleceği Girişimi}

Tam bir asırdır çalışma hayatı ile ilgili çok farklı düzenlemelere yer veren ILO bu başarısını, "çalışma yaşamının geleceği girişimi” ile taçlandırmıştır. 2013 y1lında düzenlenen 102. oturum ile temelleri at1lan, 10-21 Haziran 2019 tarihinde düzenlenen 108. oturum ile son şeklini alan ve "yüzyıl deklarasyonu" olarak adlandırılan bu girişim, bundan sonraki yüzyılı konu edinmekte ve çalışma yaşamının geleceği ile ilgili öngörüleri kapsamaktadır

\section{Tanımı}

Dış dünyada sürekli değișen demografik, ekolojik, sosyal, siyasal, ekonomik ve özellikle teknolojik şartlar, çalışma hayatı başta olmak üzere farklı sosyal politika konularını derinden etkilemektedir. Bu kapsamda ILO, yüzyıl girişimini önemli bir gereklilik olarak değerlendirmiş ve ayrıca önem vermiştir. Yüzyıl girişiminin adının ne olacağ 1 ve en çok hangi konu üzerinde durulacağı konusunda ILO 102. Oturumunda; çalışma yaşamını dönüştüren temel güçleri irdelemiş ve temelde; demografi, çevre, teknoloji, yoksulluk, eşitsizlik, uluslararası denge, üretim ve istihdam başlıklarını değerlendirmiştir (Tablo 1).

Tablo 1

Çalıșma Yașamını Dönüşüren Temel Güçler, Potansiyel Etkiler ve ILO

\begin{tabular}{|c|c|c|}
\hline $\begin{array}{l}\text { Temel } \\
\text { güçler }\end{array}$ & Potansiyel etkiler & $\begin{array}{l}\text { ILO'nun yüzleşebileceği ilgili } \\
\text { durumlar }\end{array}$ \\
\hline Demografi & $\begin{array}{l}2018 \text { yılına kadar } 44,5 \text { milyon kişinin } \\
\text { küresel işgücü piyasasına girmesi }\end{array}$ & $\begin{array}{l}\text { İş yaratma, sosyal koruma, göç, } \\
\text { piyasa kırılganlıkları }\end{array}$ \\
\hline Çevre & $\begin{array}{l}\text { Çevreyi daha az tehdit eden düşük } \\
\text { karbonlu üretim sistemi }\end{array}$ & $\begin{array}{l}\text { Sosyal diyalog mekanizmasının önem } \\
\text { kazanmas1. }\end{array}$ \\
\hline Teknoloji & $\begin{array}{l}2015 \text { y1lı ile birlikte toplamda } 1,5 \text { milyon } \\
\text { endüstriyel robotun çalışma hayatına } \\
\text { girmesi }\end{array}$ & $\begin{array}{l}\text { Eğitim ve öğretim sistemlerinin } \\
\text { güçlendirilmesi ve temel becerilerin } \\
\text { sağlanması }\end{array}$ \\
\hline Yoksulluk & $\begin{array}{l}\text { Küresel bir orta sınıfın oluşturulması } \\
\text { ihtiyacı }\end{array}$ & $\begin{array}{l}\text { İnsan onuruna yakışır işlerin önemi ve } \\
\text { insan onuruna yakışır işlere erişim. }\end{array}$ \\
\hline Eşitsizlik & $\begin{array}{l}\text { Büyümekte olan bir orta sınıfın oluştuğu } \\
\text { güzel haberlerine karşıllk bazı bölgelerde } \\
\text { esitsizliğin artmaya devam etmesi }\end{array}$ & $\begin{array}{l}\text { Konu ile ilgili ayrı bir politika } \\
\text { gündemi oluşturmalı. }\end{array}$ \\
\hline Denge & $\begin{array}{l}\text { Zengin-güçlü-dengeli ve sürdürülebilir bir } \\
\text { büyüme }\end{array}$ & $\begin{array}{l}\text { İyileşme dinamikleri içerisine insan } \\
\text { onuruna yakışır iş anlayışııı da dâhil } \\
\text { etmek için iyi bir firsat oluşturulmalı. }\end{array}$ \\
\hline $\begin{array}{l}\text { Üretim ve } \\
\text { istihdam }\end{array}$ & $\begin{array}{l}\text { Tedarik zincirlerinin küreselleşmesi, işgücü } \\
\text { piyasalarının ulusal boyuttan giderek } \\
\text { uzaklaştırması }\end{array}$ & $\begin{array}{l}\text { Özel işletmelerle daha fazla etkileşim } \\
\text { ihtiyacı }\end{array}$ \\
\hline
\end{tabular}

Kaynak: ILO, 2013, s.5. 
Belirlenen konulara bağlı kalınarak yüzyıl girişiminin adı ve kapsamını belirlemek için; "çalışma yaşamının girişimi”, "yeşil girişim”, "çalışma yaşamında kadınlar girişimi”, "yoksulluğu sonlandırma girişimi”, "işletmeler girişimi", "standartlar girişimi” ve "yönetişim girişimi” olmak üzere genel kurula yedi başlık önerilmiştir (ILO, 2013, s.6). 104. oturumda; değişim faktörlerinin iş dünyasını hızlandıracak ve büyük ölçüde değiştirecek bir düzeyde olması konusu değerlendirilmiştir. Bu nedenle raporda, ILO'nun sosyal adaleti sağlayabilmesi için bu dönüşümü anlaması ve bu dönüşüm sürecine etkin bir şekilde cevap vermesi gereği vurgulanmıştır. Bu açıdan 2013 yılı raporunda çalışma hayatını dönüştüren temel güçler değerlendirildiğinde birinci başlı̆̆ın genel kurul tarafından daha fazla desteklendiğine dikkat çekilmiş ve hedeflenen yüzyıllık girişim için daha yansıtıcı olduğu kabul edilmiştir. Bunun yanında başlığın belirlenmesinde ILO'nun yakın bir gelecekte öngördüğü ve yüzleşmek zorunda kalabileceği sorunlar da etkili olmuştur. Ayrıca küresel çapta yaşanan sorunların çözümünde bugüne kadar uygulanan politikaların kısa dönemli ve spesifik olması, yüzyıl girişiminin şekillenmesinde etkili olan bir diğer etken olarak değerlendirilmiştir. Bu kapsamda hedeflenen girişim ile ILO; uzun vadeli değişim dinamiklerini görme, resmi daha geniş algılama ve bu süreçte bir kuruluşa nelerin ihtiyaç olduğunu sorgulama firsatını elde edecektir. Bunun yanında girişimin; üst düzey bir çaba ile ele alınması, evrensel ilkelere sahip olması, açık ve anlaşılır olması, tarihsel tecrübelere dayanması, mümkün olduğu kadar geniş paydaşlara ulaştırılarak gerçekleştirilmesi ve aynı zamanda küresel iş dünyasının büyük bir belirsizlik ve güvencesizlik içerisinde ilerlemesi sonucunda önem kazanan "küresel sosyal adalet" vizyonuna önemli katkılar sağlaması noktasında değerlendirilmesi gerektiği savunulmuştur (ILO, 2015, ss.1-2). Ayrıca girişim Sürdürülebilir Kalkınma Hedefleri ve Binyıl Kalkınma Hedeflerine göre çok daha karmaşık ve modern konulara ilişkin sayısız hedefleri kapsar bir nitelik taşımaktadır (ILO, 2018a, ss.1-2).

Nitekim ILO Genel Direktörü Guy Ryder tarafından üye ülkelere gönderilen çalışma yaşamının geleceği ile ilgili 14 Aralık 2015 tarihli mektupta çalışma yaşamının geleceği girişimi; “ILO’nun yüzüncü yılı ve ötesine giden bir tarihin önemli bir dönüm noktası olacak ve zamanımızın en acil kamu politikası sorunlarına cevap verecek önemli bir araç" şeklinde tanımlanmıştır. Ayrıca Ryder, ulus devletlerin bu dönüşüm hakkındaki anlayışlarını derinleştirmesi gerektiğini, böylece herkes için "insan onuruna yakışır iş" ve ILO olarak 
"küresel adalet görevini” üstlenmeye yönelik ortak taahhüdü ilerletmeleri gerektiğini ifade etmiştir (Erişim Tarihi: 04 Nisan 2019, https://www.ilo.org/ wcmsp5/groups/public/---dgreports/---dcomm/documents/correspondence/ wcms_446487.pdf). Aynı şekilde Ryder; 19 Temmuz 2018 tarihinde "işlerin geleceğini yaratmak” CSIS (Uluslararası Çalışmalar ve Strateji Merkezi) söyleşisinde bu durumu açıklarken dünyanın; büyümekte ve yaşlanmakta olan bir nüfus, zorunlu göç, sürekli yoksulluk, kentleşme ve işgücünü etkileyen bir dizi teknolojik gelişme gibi karmakarışık zorluklarla karşı karşıya kaldığını ifade etmiş, tüm bu gelişmelerin doğru şekilde kanalize edilmesi ve yönetilmesi gereğinin önemini vurgulamış aksi takdirde insan emeğinin önemli derecede zarar göreceğini ve "en iyi sosyal program ve en iyi sosyal güvenlik, iştir" sözünün boşa çıkacağını belirtmiştir (CSIS, 2018).

\section{Süreci ve İçeriği}

ILO’nun çalışma yaşamının geleceği girişimi süreci 2016, 2017, 2018 ve 2019 yıllarını kapsamaktadır. Girişimin ilk yılı 2016 yılı için; "iş ve toplum”, "herkes için insan onuruna yakışır iş", "iş ve üretim organizasyonu" ve "işin yönetişimi” olmak üzere dört ana başlık belirlenmiş ve belirlenen dört ana başlığın her üye devlet tarafından kendi sosyal diyaloğu çerçevesinde hayata geçirilmesi istenmiştir. 2017 yılı için çalışma hayatının geleceği ile ilgili üst düzey küresel bir komisyonun kurulması öngörülmüş, 2018 yılında da üst düzey komisyonun belirlenen takvim çerçevesinde ulus devletlerden elde edeceği metaryeller ile bir rapor hazırlaması ve bunu yayınlaması istenmiştir. Son olarak 2019 yılında düzenlenecek olan 108. oturumun "çalı̧̧ma yaşamının geleceği girişiminin" doruk noktası olması ve bu oturumda "yüzyıl deklarasyonunun" kabul edilmesi planlanmıştır (Erişim tarihi: 06 Temmuz 2019, https://www.ilo.org/wcmsp5/groups/public/---dgreports/---dcomm/ documents/correspondence/wcms_446487.pdf, ). Bu kapsamda üye devletler için öngörülen dört ana başlığın sosyal diyalog yoluyla hayata geçirilmesi gerektiğine ayrıca dikkat çekilmiştir. Diyaloğun tamamen üçlü olması gerektiğine yer verilmiş ve bu amaçla ulus devletlere gönderilen mektubun aynı zamanda ulusal işverenlere, işveren kurum ve kuruluşlarına ve işçi örgütlerine gönderileceği belirtilmiştir. Ayrıca STK'ların da sürece önemli değerler katabileceği ve oluşturulan diyalog sürecine fayda sağlayabileceği dile getirilmiştir (Erişim tarihi: 06 Temmuz 2019, https://www.ilo.org/global/topics/future-of-work/ WCMS_446487/lang--en/index.htm). 
2017 yılı için ILO’nun çalışma yaşamının geleceği ile ilgili amac1; 2016 yılı için belirlenen sosyal diyalog kapsamında gerçekleştirilen faaliyetleri ve gerekli görülebilecek diğer konulardan ve materyallerden elde edilen çıktıları incelemek olan üst düzey küresel bir komisyonun kurulması olmuştur. Buna göre 2017 yılında oluşturulan komisyon başkanlığında; İsveç Başbakanı Stefan Lövfen ile Güney Afrika Cumhuriyeti Devlet Başkanı Matamela Cyril Ramaphosa bulunmaktadır (Erişim Tarihi: 06 Temmuz 2019, https://www.ilo.org/global/ topics/future-of-work/WCMS_569528/lang--en/index.htm). 2018 y1lında oluşturulan küresel komisyon; herkes için iyi ve sürdürülebilir iş olanakları sağlayan bir çalışma hayatının geleceğine ilişkin ve buna nasıl ulaşılacağına dair bağımsız bir rapor hazırlamıştır. Rapor 22 Ocak 2018 tarihinde, 2019 yılı 108. ILO konferansında sunulmak üzere Cenevre'de yayınlanmıştır. Bu kapsamda rapor; 18 ay boyunca 110'dan fazla üye devletin hükümetler, işveren ve işçi örgütleri arasında gerçekleştirdikleri iş ve toplum, herkes için insan onuruna yakışır iş, iş ve üretim organizasyonu, işin yönetişimi başlıkları altında gerçekleştirdikleri sosyal diyalogları kapsamaktadır. Buna göre küresel komisyon raporunda, çalışma yaşamının geleceğini şekillendiren üç temel faktör belirlenmiştir. Bunlar (ILO, 2019; CICOPA, 2018):

- Teknolojik değişim, dijitalleşme ve bilgi tabanlı ekonomi,

- Küreselleşme ve sanayisizleşme,

- Demografik, toplumsal ve çevresel değişim,

Bu faktörlere ek olarak sebepten çok sonuç özelliği taşıyan;

- İşin ya da yapılandırılmasının çalışma koşulları, eşitsizlik ve sosyal koruma üzerindeki etkileri,

faktörü de eklenmiştir (CICOPA, 2018).

Bahsedilen faktörlerden özellikle teknolojik gelişmeler ve hızlı dijitalleşme, bilgi tabanlı ekonomi çerçevesinde ekonomik işleyişi derinden etkileyen faktörlerin başında gelmektedir. Aynı şekilde yaşanan dijitalleşmeye bağlı olarak hızla gelişen ulaşım ve iletişim faktörlerinin küreselleşmenin boyutunu ve yönünü değiştirecek bir öneme sahip olması, çalışma yaşamının geleceğinde yadsınamaz bir boyutu oluşturmaktadır. Öte yandan demografik faktör bağlamında ülkelerin sahip oldukları genç ve yaşlı nüfus oranları ve bu oranların 
zaman içinde değişecek olması, çalışma hayatını yakından ilgilendiren bir diğer faktördür. Nitekim bu durum; doğum oranları, ölüm oranları, işgücüne katılım oranları, işsizlik ve sosyal güvenlik konuları başta olmak üzere birçok sosyal politika konusunu kapsar bir nitelik taşımaktadır. Üretim sürecinde farklı sektörlerde kullanılan kimyasalların ve neden oldukları gazların atmosferik etkileri, buna bağlı olarak yaşanılan küresel iklim sorunları ve bunun sosyal maliyeti, işletmelerin bu süreçteki tutumları ve benimsedikleri politikalar, işgücü piyasalarının geleceğini şekillendiren bir diğer faktör olarak değerlendirilmektedir. Bunun yanında işgücü piyasalarında yaşanan gelişmelerin daha çok sonucu niteliğinde değerlendirilebilecek olan eşitsizlik sorunu ve dolaysıyla her geçen gün daha çok ihtiyaç duyulan sosyal koruma ihtiyacı bir diğer önemli faktör olarak karşımıza çıkmaktadır.

\section{Teknolojik Değişim ve Bilgi Tabanlı Ekonomi}

İleri teknolojilerin özellikle iletişim teknolojilerinin giderek bir bilim toplumu yeni ismiyle "küresel köyü" oluşturması, mal ve hizmetlerin dünya çapında çok uluslu ve ulus ötesi şirketler aracılığı ile üretildiği ve pazarlandığı evrensel bir çerçeveyi oluşturmuştur (Dereli, 2001). Bu yönüyle dünya; işçilerin, üreticilerin ve tüketicilerin küresel alanda daha fazla yayıldı̆̆ 1 derin ve radikal bir teknolojik değişim dalgası içine girmiştir (CICOPA, 2018). Bu durum üretim sürecinde insanın, çoğunlukla makineler arasında kalan boşlukları dolduran, diğer bir ifade ile üretim sürecinde sürekli rolü azalan taraf olarak değerlendirilmesine (Ford, 2018, ss.20-21) yol açmıştır.

İnsanlar tarafından yapılan işlerin giderek artan oranda yenilikçi düşünceyi, esnekliği, yaratıcılığ 1 ve sosyal becerileri kapsayan yönüyle bilgi tabanlı ekonomiler, sürecin şekillenmesinde önemli bir paya sahiptir. Özellikle toplumların biyoteknoloji, bilgisayar mühendisliği, nanoteknoloji, robotik, telekomünikasyon, veri yönetimi, e-eğitim vb. bilgi yoğun alanlara yatırım yapmaları bilgi tabanlı ekonomiyi giderek yaygınlaştırmaktadır. Bilgi tabanlı ekonomide özellikle mal ve hizmetlerin çevrimiçi platformlar üzerinden sunumu büyük önem taşırken değişimin ana faktörünü bilgi teknolojileri oluşturmaktadır. Özellikle geleneksel teknolojinin yetersiz kaldığı günümüz iş piyasalarında ön plana çıkan işverenle işçinin sanal bir bağ kurarak çalışmasını sağlayan "dijital çalışma platformları” bunun en iyi örneklerini oluşturmaktadır. Bu kapsamda örneğin Cornell Üniversitesi öğrencileri tarafından ABD'de oluşturulan 
üyelerinin çoğunluğunu göçmen Latin kadınların oluşturduğu COOPIFY platformunda temizlik ve yaşlı bakımı gibi işlere yönelik hizmetler verilmektedir. Bir dizi taksi şoförüne ait UNION TAXI, geleneksel taksi şirketlerine göre daha iyi rekabet edebilmek için oluşturulmuş ayrıca çalışanlarına daha iyi ücret ve çalışma koşulları sunma hedefi ile hayata geçirilmiştir. Bunun yanında 100 binden fazla bağımsız çalışanı bulunan ve bir Belçika kooperatifi olan SMART, üyelerine faaliyetlerini yürütmek için bir paylaşım şirketi ve dijital bir platform sunmaktadır. Kanada'da STOCKSY, Arjantin'de G-COOP ve EssApp benzer şekilde faaliyet gösteren şirketlerden bazılarıdır. Bu kapsamda işgücü piyasasında etkin olan dijital platform modeli; üyelerinin bireysel üretici olduğu, sabit ücretin garanti edilmediği, ortak bir sosyal korunmanın sağlanmadığı ve her bir üretici veya serbest meslek sahibinin kendi girişimcilik risklerini üstlendiği ancak üreticiler tarafından demokratik bir kontrol ortamının sağlandığı bir sistemi ifade etmektedir (CICOPA, 2018).

\section{Küreselleşme ve Sanayisizleşme}

Artan akışkanlıkları ve insanların, nesnelerin, mekânların, bilginin büyüyen çok yönlü akışları ile bunların karşılaştığı yapıları içeren gezegen çapındaki bir ya da bir dizi süreç (Ritzer, 2011, s.46) olarak tanımlanan küreselleşme ile son otuz yıllık dönemde önemli dönüşümler yaşanmıştır. Üretim sürecinde bu dönüşüm, ya maliyeti düşük olan yerde ya müşterilerin bulunduğu yerde ya da her ikisinde de meydana gelme eğilimi göstermiştir. Aynı şekilde bu süreç küresel tedarik zincirlerinin güçlenmesiyle birlikte dünyanın çeşitli bölgelerini de içeren karmaşık ve çok aşamalı bir şekilde iyi ve kaliteli olarak yaşanmaktadır. Bunun bir sonucu olarak sanayileşmenin farklı ülkelerde yoğunlaşması büyüme kadar, sanayileşmiş ülkelerde sanayisizleşmeyi (başka yere yatırım yapmayı ya da hizmet sektörüne kaymayı) de beraberinde getirmiş̧tir. Bu süreçte küreselleşmenin üretim ve dağıtım zincirlerinde firmalara; kendi üretim zincirlerinde kalmalarında, süreci kendi lehlerine kullanmalarında ve zorunlu olan değişimi sağlamalarında gerekli olan esnekliği sağlaması belirgin bir etki olarak karşımıza çıkmaktadır. Çoklu merkezîleşme olarak adlandırılan bu süreç adem-i merkezi bir yapıdan farklı olarak hem kurumun asıl bünyesinde hem de yeni işlerin yaralatılmasının önünü açmaktadır. $\mathrm{Bu}$ kapsamda örneğin 100 bin bağımsız çalışanı ile Belçika'da faaliyet gösteren SMART yan ürün (spin-off) modeline göre uluslararasılaşan bir yapı örneği taşımaktadır (CICOPA, 2018). 
Öte yandan çok sayıda küresel kuruluşun önemli rol oynadığı sürecin şekillenmesindeki ana amaç bir görüşe göre kardır. Bu durum özellikle bazı ülkelerde var olan eksik, düzensiz ve zayıf; politik, ekonomik ve sosyal sistemlerin büyük uluslararası şirketlerin ve dünya lideri ülkelerin önünü açmasından ve onlara boş bir alan sunmasından kaynaklanmaktadır. Kar odaklı şekillenen süreçte ise çoğu zaman düşük ücretler, kötü çalışma koşulları, kirlilik, çevre sorunları vb. birçok sorun göz ardı edilmektedir (Bulajic ve Domazet, 2012, s.1322). Bu noktada ILO, küreselleşme sürecinin daha demokratik yönetilmesi, tüm ülkeler ve insanlar için firsatlar sunması ve somut faydalar sağlaması için çabalamaktadır. Küreselleşmenin çeşitli yönlerini kapsayan bu süreç ve amaçlar bütünü, "adil küreselleşme” olarak adlandırılmıştır. Adil küreselleşme amacı; teknolojinin yayılması, fikir akımları, mal ve hizmet alış verişi, sermaye ve finans, çalışan kadın ve erkekler, sosyal koruma, sosyal diyalog vb. çok sayıda konuyu kapsayan (ILO, 2008, ss.5-6) geniş yelpazeyi ifade etmektedir

\section{İşin Yeniden Yapılandırılmasının Çalışma Koşulları, Eşitsizlik ve Sosyal Koruma Üzerindeki Etkileri}

İşin yeniden yapılandırılması sürecinde görülen en önemli etki standart dış1 çalışma ilişkilerinin yaygınlaşması şeklindedir (CICOPA, 2018). Standart dış1 çalışma ilişkilerinde görülen bu yaygınlaşma gelişmiş ülkelerde olduğu gibi gelişmekte olan ülkelerde de görülmektedir. Örneğin: 2015 yılı sonunda İngiltere'de çalışanların \%2,5'i ücret ve çalışma saatinin sabit olmadığı ve önceden belirlenmediği “sıfır saat iş sözleşmesi” ile çalışmaktadır. ABD'de işgücünün \%10’u en düşük gelirli işlerden etkilenen, düzensiz ve çağrı üzerine çalışmaya dayalı işlerde çalışmaktadır. Bangladeş ve Hindistan'da ücretli istihdamın yaklaşık 2/3'ü geçici iken Mali ve Zimbabve'de bu oran 1/3 civarındadır. Asya ülkelerinde taşeron istihdamında önemli oranda artışlar görülürken, Hindistan'da 1970'li yılların başında ihmal edilebilir düzeyde olan sözleşmeli çalışanlar 2011-2012 yıllarında \%34,7’ye yükselmiştir (ILO, 2016). Bu süreçte artan standart dışı çalışanların yaşamış oldukları en önemli problemin ise "sosyal haklara" erişim olduğu dile getirilmektedir. Diğer bir ifade ile standart dışı çalışanların sadece \%29'u kapsamlı bir sosyal güvenlik sistemine erişim hakkı elde edebilmektedir (CICOPA, 2018). Bu durum aynı zamanda toplumsal anlamda eşitsizlik sorununun ortaya çıkmasındaki en temel etkenlerden birini oluşturmaktadır. 
Aynı şekilde toplumsal alanda meydana gelen kutuplaşma, gelirin üretim faktörleri arasındaki dağılımını değiştirmektedir. Buna göre genellikle bir yanda nitelikli işlerde çalışanların, diğer yanda niteliksiz ve ücret düzeyi düşük olan işlerde istihdam edilen kadınlar, gençler ve yabancı işçilerin bulunduğu bir işgücü piyasası oluşmaktadır (Erdut, 1998, ss.148-149). Bunun bir sonucu olarak kayıtdışına çıkma eğilimi artış göstermekte ve daha fazla insan resmi istihdam düzenlemelerinden uzaklaşmaktadır. Günümüzde gelişmiş ekonomilerde bile önemli büyüklüklere ulaşan kayıtdışı istihdam, mevcut sosyal güvenlik sistemleri tarafından uygun olmayan ve kayıtdışı ekonomiden kaynaklanan çalışma biçimlerini kapsayan bir nitelik taşımaktadır. Bu gelişme "uberizasyon" fenomeni ile de açıklanmaktadır (Schwab, 2018, s.29; CICOPA, 2018).

Öte yandan ILO, standart dışı istihdam ile ilgili raporunda; standart dışı işlerin kalitesini arttırmak ve çalışma şartlarını iyileştirmek için spesifik politikalara ihtiyaç duyulduğunu vurgulamaktadır. Bu politikalar ile beklentileri karşılamak, gençler ve göçmenler gibi dezavantajlı grupların işgücü piyasalarına erişimini kolaylaştırmak ve standart dışı çalışanların daha iyi standartlara sahip işlere geçme fırsatlarını sunmak gibi amaçların daha olanaklı hale geleceğini belirtmektedir. Buna göre ILO raporunda (2016) İşin yeniden yapılandırılması sürecinde; sıfır saat çalışma, serbest çalışma, geçici işler, yarı zamanlı işler gibi yaygınlaşan standart dışı çalışma ve kayıtdışı çalışma şekillerinin sosyal güvence, iş güvencesi, eşitsizlik vb. sorunlara kaynaklık ettiği görülmektedir. Nitekim bu durum ILO tarafindan da önemli bir sorun alanı olarak kabul edilmekte ve yasal boşlukların doldurulması, toplu pazarlığın güçlendirilmesi, asgari çalışma saatlerinin düzenlenmesi, sosyal korumanın güçlendirilmesi, girişimcilik faaliyetlerinin desteklenmesi gibi politikalar çerçevesinde şekillenmektedir.

\section{Demografik, Toplumsal ve Çevresel Değişimler}

Dünyada yaşlanma sorunu ile karşı karşıya kalan ülkelerde temelde doğurganlığın azalması ve yaşam beklentisinin artması eğilimleri ön plana çıkmaktadır. 60 yaş ve üstü dikkate alındığında gelişmiş ülkelerde günümüzde \%20 civarında olan bu oranın 2050 yılında \%50'ye ulaşması, gelişmekte olan ülkelerde ise $\% 9$ civarında olan bu oranının 2050 yılında \%20'lere yükselmesi beklenmektedir. Bunun yanında çalışma çağındaki nüfusun (25-59 yaş) 20102050 yılları arasında gelişmiş ülkelerde toplam nüfusun \%49'undan \%41'ine düşeceği, az gelişmiş bölgelerde \%43'lerden \%46'ya kadar yükseleceği tahmin 
edilmektedir. Eğitim, beceri ve geliştirme odaklı üç boyutlu etkisinden bahsedilen bu öngörülerin birinci etkisini; ekonomik büyümede, özellikle kadınların ve yaşlı işçilerin artan işgücüne katılım oranlarıyla tanımlanan işgücüne verimliliğine bugün olduğundan daha fazla ihtiyaç duyulacağı beklentisi oluşturmaktadır. Yaşam boyu öğrenmenin önemini ön plana çıkaran bu durum özellikle nüfusu hızla yaşlanan (Çin gibi) ülkeler için yaşlı işçilerin büyüyen havuzuna odaklanma ve bu gruptaki nüfusun becerilerini geliştirme zorunluluğunu ön plana çıkarmaktadır. İkinci etki ise bazı bölgelerde genç grupların artan boyutu ile daha fazla genç insanın iş dünyasına gireceği bu nedenle hem eğitim hem de gelişme kapasitelerine odaklanma ve yeni iş yaratma stratejileri oluşturma süreçlerinin daha da önem kazanacağı tahminidir. Son olarak üçüncü etki ise göçmenlerin uluslararası akışkanlığının büyüyerek devam edeceği dolayısıyla bu gruptaki nüfusun eğitim olanaklarının ne olacağı ve gittikleri ülkelerde yaşayacakları beceri boşluklarının nasıl doldurulacağı konusunun önem kazanacağıdır (ILO, 2010, ss.7-8). Bu kapsamda demografik anlamda yaşanan gelişmelerin işgücü piyasalarına etkileri; yaşlı nüfus, genç nüfus ve göçmen nüfus olmak üzere temelde üç taraflı gerçekleşmektedir. Her üç grubun kesişim noktasını ise vasıflandırma oluşturmaktadır. Vasıflandırma süreci yaşlı nüfusta verimliliği arttırma ve daha fazla çalışma hayatında tutma amacı ile şekillenirken, genç nüfusta mevcut işgücü piyasasına hazırlama amacı ile ön plana çıkmaktadır. Göçmen nüfusta ise, daha çok uyum sağlama amacı ile önem kazanmaktadır. Bu kapsamda demografik değişim sürecini ILO, işgücü piyasalarına etkileri açısından değerlendirmiş ve ülkelerin karşılaşabileceği durumlar ile ilgili öngörülerde bulunmuştur.

Öte yandan nüfusun yaşlanması, gençleşmesi, ulusal ya da uluslararası akışkanlığı toplumsal yapıların değişmesinde de önemli bir etkiye sahiptir. Bu gelişme mal ve hizmetlere duyulan ihtiyaç ve taleplerin sürekli olarak farklılaşmasına yol açmaktadır. Ortaya çıkan bu yeni ihtiyaçlar yalnızca tüketicilerin tercihleriyle değil aynı zamanda çevresel bozulma, iklim değişikliği, göç, mülteci krizi, yaşam beklentisi artışı vb. etkilerle de görülmektedir. $\mathrm{Bu}$ kapsamda örneğin bilişim faaliyetlerinin genişlemesi, sağlık ve sosyal hizmetler, çevrenin korunması, enerji üretimi, kültür, tasarım, eğlence, seyahat vb. faktörler bu değişim sürecinde önemli rol oynamaktadır (CICOPA, 2018). Bu nedenle sürdürülebilir kalkınma ve çevre korumanın ekonomik ve sosyal kalkınma hedeflerine entegrasyonu, ulusal ve uluslararası politika gündeminde en zorlayıcı konular arasına girmiştir (ILO, 2010, s.13). 


\section{Çalışma Hayatının Geleceğinde Niteliği Değişen Dış Kaynak Kullanımı}

Günümüz iş dünyasında iç kaynak kullanımı firmalara; dış kaynak kullanan firmalarla rekabet edememe ve dış kaynak rekabetinde artan işçilik maliyetleri gibi negatif etkilere karşılık üretim faaliyetlerinin kontrolü ve sadık işgücü konusunda pozitif etkiler sağlamaktadır. Buna karşılık üretim sürecinde azalan kontrol kaybı, raporlama ve muhasebe sorunları, gücenmiş çalışanlar, moral bozukluğu negatif etkilerine karşılık üretim maliyetlerinde görülen önemli düzeyde düşüşler, operasyonel riski yayma, üretim faaliyetlerinde çeşitlilik ve diğer pozitif etkiler dış kaynak kullanımını iç kaynak kullanımından daha cazip hale getirmiştir. Dış kaynak müşterisi ile dış kaynak sağlayıcısı arasında çok farklı şekillerde gerçekleşebilecek olan bu tür işbirliği türleri, farklı bağımlılık derecelerine göre gerçekleşebilmekte (Schniederjans, Schniederjans ve Schniederjans, 2005, ss.4-5) ve farklı özellikteki organizasyonlarda üretim sürecinde yaşanan gelişmelere bağlı olarak şekillenebilmektedir (Tablo 2).

Tablo 2

Organizasyonların Gelişimi ve Dış Kaynak Kullanımının Değişen Niteliği

\begin{tabular}{|c|c|c|}
\hline Geleneksel organizasyonlar & Günümüz organizasyonları & $\begin{array}{c}\text { Gelecekte } \\
\text { organizasyonlar }\end{array}$ \\
\hline $\begin{array}{c}\text { Çoğunlukla imalat } \\
\text { sektöründe diş kaynak } \\
\text { kullanılır ve "taşeronluk" } \\
\text { ifadesi kullanılır }\end{array}$ & $\begin{array}{l}\text { İmalat sektörünün yanında hizmet } \\
\text { sektöründe dış kaynak kullanımı } \\
\text { yaygındır, "dış kaynak kullanımı" } \\
\text { ifadesi kullanılır }\end{array}$ & $\begin{array}{c}\text { Sanal organizasyonlar } \\
\text { ağırlıktadır }\end{array}$ \\
\hline $\begin{array}{l}\text { Çoğunlukla maddi ürünler } \\
\text { dış kaynaklı sağlanır (imalat } \\
\text { sektörü) }\end{array}$ & $\begin{array}{l}\text { Maddi ürünlerin yanında maddi } \\
\text { olmayan hizmet eksenli kaynaklara } \\
\text { daha fazla yer verilmektedir }\end{array}$ & $\begin{array}{l}\text { Firma için kritik önem } \\
\text { taşıyan işler dişında } \\
\text { tüm ticari faaliyetler dış } \\
\text { kaynaklıdır }\end{array}$ \\
\hline $\begin{array}{c}\text { Toplam üretim } \\
\text { faaliyetlerinin küçük bir } \\
\text { kısmı dış kaynaklı sağlanır }\end{array}$ & $\begin{array}{l}\text { Toplam üretim faaliyetlerinin orta } \\
\text { düzeyde kısmı dış kaynaklı sağlanır }\end{array}$ & \\
\hline $\begin{array}{l}\text { Çoğunlukla yurtiçi dış } \\
\text { kaynak kullanımı yaygındır, } \\
\text { çok az küresel dış kaynağa } \\
\text { yer verilir }\end{array}$ & $\begin{array}{l}\text { Yurt içi kaynaktan daha çok küresel } \\
\text { dış kaynaklara başvurulmaktadır. }\end{array}$ & $\begin{array}{l}\text { Önemli oranda küresel dış } \\
\text { kaynak kullanımına yer } \\
\text { verilir }\end{array}$ \\
\hline
\end{tabular}

Kaynak: Schniederjans, Schniederjans ve Schniederjans, 2005, s.6.

Geleneksel organizasyonlarda dış kaynak kullanımı, genelde taşeronluk ifadesi ile tanımlanırken çoğunlukla imalat sektöründe başvurulan bir üretim sistemi olarak karşımıza çıkmaktadır. Bunun yanında dışarıdan sağlanan faaliyetler oldukça dar kapsamda olup çoğunlukla yurtiçinden karşılanmaktadır. Günümüzde ise dış kaynak kullanımı kavramının daha yaygın kullanıldığı, çoğunlukla hizmet sektöründe başvurulduğu, üretim faaliyetlerinin geleneksel organizasyonlara oranla daha fazla dışardan sağlandığı ve küresel dış kaynaklara daha fazla 
başvurulduğu görülmektedir. Gelecekte ise organizasyonların çoğunluğunun sanal organizasyonlar olduğu dikkate alındığında dış kaynak kullanımına daha sık başvurulacağı ve daha fazla küresel hareket edileceği beklenmektedir.

Benzer bir ayrım geleneksel dış kaynak kullanımı ve yeni nesil dış kaynak kullanımı şeklinde de yapılmıştır. Geleneksel dış kaynak kullanımının özellikleri; tasarruf odaklı, deniz aşırı ve işgücü arbitrajından faydalanma amaçlı, zamana dayalı, işlem odaklı, kapsamlı ve kalıcı anlaşmalar çerçevesinde küresel anlamda daha dar kapsamlı, sınırlı analiz ve sınırlı akıllı otomasyon çerçevesinde şekillenmektedir. Yeni nesil dış kaynak kullanımı ise katma değer ve stratejik servis odaklı, deniz aşırı ve işgücü arbitrajından faydalanma amaçlı, sonuca ve değere bağl1, katma değer ve stratejik çalışma sürecine bağlı, dar kapsamlı ve geçici anlaşmalar çerçevesinde, hızlı ve agresif davranılan, yoğun otomasyon ve ileri düzeyde veri analizi içeren bir sistem çerçevesinde şekillenmektedir (Lepeak, 2018). Bu iki paradigma arasında stratejik amaçlar, dış kaynak kullanım kararının alınma zamanı, pazar yapısı, kurumsal özellikler ve işleyişler, tedarikçi arayüzü, bilgi teknolojilerinin kullanım boyutu, performans algısı ve ölçümü ve eksi yönler açısından önemli farklılıklar bulunmaktadır. Buna göre yeni paradigma; küresel rekabet, risk, entelektüel tabanlı sistemler, küresel ve sektörel pazarlar, sanal yapılar, sanal organizasyonlar, ağa bağlı platform yapılar, küçülme, esneklik, uzmanlaşma, inovasyon, yazılım tedarikçileri, e-ticaret, karmaşık koordinasyon, zaman sıkıntısı, mülkiyet sınırı konusu vb. kavramlar çerçevesinde anlam kazanmaktadır (Kakabadse ve Kakabadse, 2000, ss.716-717).

Diğer bir ayrıma göre dış kaynak kullanımının değişen niteliği; birinci tip, ikinci tip ve üçüncü tip şeklinde incelenmiştir. Bu ayrıma göre birinci tip dış kaynak kullanımı üretim işlerinde görülürken, ikinci tip dış kaynak kullanımı 1990'lardan itibaren idari işlerde görülmeye başlamıştır. Üçüncü tip ise günümüzde teknoloji tabanlı görülen ve çevirimiçi dış kaynak kullanımı şeklinde de tanımlanan önemli bir ekonomik dönüşümü ifade etmektedir. Daha çok çevirimiçi işgücü piyasalarını etkileyen üçüncü tip dış kaynak kullanımı teknolojinin ucuzlaşması ve internet kullanımının yaygınlaşması ile önem kazanmıştır (Ray, 2017).

Öte yandan küreselleşme sürecinde dış kaynak kullanımının niteliğinin değişmesinde 1990'lı yılların ortalarında yaşanan ekonomik patlama sürecinin de önemli bir etkisinin olduğu dile getirilmektedir. Bu dönemde yaşanan 
Meksika, Brezilya, Güneydoğu Asya, Arjantin, Türkiye gibi ülkelerde yaşanan bir dizi kriz süreci dış kaynak kullanımının yelpazesini, gelişmiş ülkelerdeki şirketlerin gelişmekte olan ülkelerdeki işletmelere iş göndermesi ile genişletmiştir. Yine aynı dönemde;

- Niş pazarlarının önem kazanması,

- Çin'in uzun zamandır dış kaynak hizmetleri sağlama konusunda lider konumda olan Hindistan ile rekabete geçmesi,

- Küresel şirketlerin dış kaynak kullanımında teknolojiye ağırlık vermesi,

- Küçük ve orta ölçekli işletmelerin de küresel dış kaynak kullanımına yönelmeleri,

- Küresel firmaların uzun vadede çok daha fazla değişiklik yaşanacağını öngörmeleri,

- Firmaların her geçen gün daha karmaşık yapıda bilimsel ve Ar-Ge projelerine dâhil olmaları,

- Küresel rekabet sürecinde yeni ve karmaşık görevlerin ortaya çıkması,

- Dış kaynak kullanımında maliyet faktörünün tek faktör olarak görülmemesi vb. gelişmeler,

dış kaynak kullanımını oldukça girift bir yapı kazandırmıştır (Leavitt, 2007).

Bu kapsamda günümüzde ekonomiklik, kalite ve yenilik gibi kavramlar dış kaynak kullanımının tanımlanmasında ve açıklanmasında oldukça yetersiz bulunmaktadır. $\mathrm{Bu}$ değişen paradigmayı tanımlamak için önem kazanan kavramların başında; bilgi transferi, davranış, ticari risk ve müşteri memnuniyeti gelmektedir. Keiretsu modelinin batılılaşması şeklinde de tanımlanan bu yeni paradigma; yüksek düzeyde bilgi şeffaflı̆̆ı gerektirmesi, çeşitli derecelerde karşılıklı sahiplenme ve güven esası ile gerçekleşmesi özellikleri ile tanımlanmaktadır (Kakabadse ve Kakabedse, 2000, ss.716-717). Küreselleşme süreci ile başlayan bu değişim sürecinin şekillenmesinde; 1990'lı yılların ortalarında özellikle gelişmekte olan ekonomilerde görülen ekonomik krizler, yine aynı dönemde idari işlerin dış kaynağa verilmesi ve özellikle 2000'li yılların başından itibaren bilişim ve Akıllı Otomasyon Teknolojilerinin (AOT) ucuzlaşması ve yaygınlaşması büyük rol oynamıştır. 
Nitekim günümüzde dış kaynak kullanımının niteliği en başta teknolojiye bağlı olarak değişmeye devam etmekte ve şirketler yıllık dış kaynak ihtiyacı belirlemek zorunda kalmaktadırlar. Örneğin 2019 yılı için dış kaynak kullanımında Bilişim Teknolojilerinin (BT) önem kazanacağı öngörülmüş ve bu kapsamda altı temel trend belirlenmiştir. Bu kapsamda; BT becerilerindeki yetersizlik önemli bir dürtü olarak kabul edilmiş, alternatif dış kaynak kullanım hedeflerinin oluşturulması ve siber güvenlik ve uyumluluk konularına daha fazla odaklanılması gereği vurgulanmış, sanal ve arttırılmış gerçeklik projelerindeki yükseliş, yapay zekâ ve otomasyon konularına dikkat çekilmiş, BT dış kaynak ortaklıklarının niteliğinin değiştirilmesi gereği vurgulanmıştır. Belirlenen trendler kapsamında İngiltere'de işverenlerin \%70'inden fazlasının 12 ay boyunca yetenek sıkıntısı çekeceği, Doğu Avrupa ülkelerinin sıkça dış kaynak temin ettiği Hindistan ve Çin arasında güçlü bir rekabet beklenmekte olduğu, Polonya, Ukrayna, Romanya ve Beyaz Rusya'nın dış kaynak sağlama noktasında sıcak noktalar olacağı, özellikle Ukrayna'nın bilişim sektörü dinamiklerinin sürekli arttığı, ülkeler bazında tüm veri setlerinin tamamen şifrelenmesi talebinin artacağı, ulusal veya uluslararası düzeyde kamu ya da özel kurumlarda siber saldırıların büyük tehdit olacağı belirtilmiştir. Aynı şekilde izleme, ölçme, işleme, yükseltme, 3B algılama, gelişmiş hareket tanıma vb. kontrollerin önem kazanacağı, Robotik Süreç Otomasyonu (RSO) ve Yapay Zekânın (YZ) gelecekte dış kaynak trendlerini şekillendirecek faktörler olduğu da vurgulanmıştır. Küresel Kaynak Derneğinin 2018'de yapmış olduğu bir araştırma belirlenen trendleri destekler niteliktedir. Buna göre yapılan araştırmaya göre ankete katılan şirketlerin \%70'i önümüzdeki yıllarda daha fazla dış kaynak kullanacağını belirtmiş, \%35'i bu sürece hayati önem vereceğini bildirmiştir. Bunun yanında hizmet sağlayıcı konumunda olan şirketlerin \%84'ünün dış kaynak bağımlısı haline geleceği de tahmin edilmiştir. 2020 yılı için ise ihtiyaç duyulan dış kaynak kullanım becerileri şu şekilde belirlenmiştir: Dijital dönüşüm (\%76), dönüşüm mimarlığı (\%63), otomasyon uzmanlığı (\%58), müşteri odaklı yönetim (\%45), operasyon stratejileri (\%42), tasarımcı ve fikir adamlığı (\%38) (Devabit, 2018).

Öte yandan ISS'a göre (Uluslararası Servis Sistemi) göre dış kaynak kullanımının geleceğini şekillendirecek olan mega trendler şu şekildedir (ISS, 2016, s.25): Ekonomik büyüme, küreselleşme, ticarileşme, sürdürülebilirlik, bireyselleşme, ağ toplumu, demokratikleşme, sağlığa odaklanma, kutuplaşma (polarizasyon), soyutluluk, bilgi toplumu, teknolojik gelişim, hız ve karmaşıklık, 
demografik gelişim. Ayrıca bu süreçte özellikle AOT'un dış kaynak kullanımının geleceği üzerinde belirleyici bir etkisinin olacağı öngörülmektedir. Bunun yanında diğer etkenler şu şekilde tahmin edilmektedir (Lepeak, 2018): Katma değer ve daha stratejik hizmetler, AOT, veri analiz ve yapay zekânın fonksiyonel olarak benimsenmesi, bulunması zor yüksek vasıflı işgücüne (veri bilimcileri, endüstriyel ve fonksiyonel veri analitik uzmanları, gelişmiş yapay zekâ konusunda farklı becerilere sahip çalışanlar gibi) erişim ihtiyacı, yapay zekânın beyaz yakalılar üzerindeki yıkıcı etkileri vb.

\section{Teknolojik Değişim ve Bilgi Tabanlı Ekonomide Dış Kaynak Kullanımı}

Dış kaynak kullanımı veya faaliyetlerin firma dışındaki taşeronlara yaptırılması küreselleşme ile birlikte özellikle son yıllarda daha yaygın hale gelmeye başlamıştır. Örneğin Magnani’n 2006 yılında yapmış olduğu bir araştırmaya göre dış kaynak kullanımı ABD'de ve Avrupa ülkelerinde 20.yy'ın ikinci yarısında yaklaşık üç kat artmış göstermiştir (Bartel, Lach ve Sicherman, 2008, s.2). Çok farklı nedenlere bağlı olarak açıklanan bu gelişmede en önemli etken olarak "teknoloji” faktörü gösterilmektedir. Ancak dış kaynak kullanımının artması ile teknoloji boyutu arasındaki ilişkiyi ortaya koyan çalışmalar oldukça azdır. Literatürde bu boşluğu dolduran en önemli araştırmalardan birini “Dış Kaynak Kullanımı ve Teknolojik Yenilikler: Firma Düzeyinde Bir Analiz” (Outsourcing and Technological Innovations: A Firm-Level Analysis) araştırması oluşturmaktadır. İspanyol firmalarının 1990-2002 yılları arası faaliyetleri dikkate alınarak 2008 yılında yapılan bu araştırmaya göre; teknolojide meydana gelen hızlı gelişmeler dış kaynak kullanımını daha avantajlı hale getirdiğinden firmalar bu üretim sistemini daha etkileyici bulmaktadırlar. Yine aynı araştırmaya göre bu durum temelde teknolojide meydana gelen yeniliğin sıklaşmasına bağlı olarak firmanın eski teknolojiler ile ilgili batık maliyetlerini amorti edebilecek yeterli zamanının olmamasından kaynaklanmaktadır. Bu noktada firmanın en son teknolojiyi kullanan firmalarla işbirliği yapması sıkı rekabet ortamında firmaya önemli avantajlar sunmaktadır (Bartel, Lach ve Sicherman, 2008, ss.20-21).

Dış kaynak kullanımının niteliğini değiştiren bir diğer faktör de özellikle küresel işletmelerde görülen hızlı dijitalleşmedir. 2018 dijital dönüşüm endeksine göre; işletmelerin \%40'1ndan fazlası işyerinde özel bir dijital dönüşüm ekibine sahip olduklarını belirtmiştir. Bu kapsamda birçok kuruluş teknolojik değişimin hızlı ilerlemesine uyum sağlamak ve böylelikle rekabet gücünü korumak amacıyla 
BT dış kaynak ortaklıklarına yönelmektedir. Bu yönelme geleneksel çıktıya dayalı yaklaşımlardan çok entegre ve özel düzenlemelere bağl gerçekleşmektedir. $\mathrm{Bu}$ nedenle daha esnek sözleşme modelleri ile en iyi teknik uzmanlığ sağlayabilecek BT ortaklarına olan ihtiyaç, her geçen gün daha da artmaktadır. Yine bu kapsamda firmalara teknoloji alanında dış kaynak kullanımına yönlendiren en etkili faktörler şu şekilde sıralanmaktadır: Yapay zekâ, güvenlik açığı, yeni akıllı otomasyon modelleri, yeni hizmet dağıtım modelleri. Buna göre yapay zekâ konusunda derin bir uzmanlık sağlayan dış kaynak firmaları örneğin "blok zinciri” (blockchain) gibi teknolojiler sunan firmalar büyük talep görmektedir. Aynı şekilde ekonomik ilişkilerin dijitalleşmesi ile beliren güvenlik açığı ve açığı dolduracak olan dış kaynak sağlayıcıları, özellikle siber güvenlik konusunda kendisini kanıtlamış şirketler üretim ilişkilerinde büyük önem taşımaktadır. Bunun yanında teknolojik gelişmelere bağlı olarak ortaya çıkan şirketlerin akıllı otomasyon ihtiyacı, dış kaynak kullanımı etkileyen bir diğer faktördür. Bu süreçte işletme operasyonlarını kolaylaştırma ve insan girdisinin daha yüksek değerli çalışmaya odaklanmalarını sağlama amaçları belirleyici bir etkiye sahiptir. Öte yandan "hizmet dağıtım modellerinde" yaşanan devrim, dış kaynak kullanımını dönüştüren bir diğer etken olarak görülmektedir. Bu noktada birçok kuruluş, yalnızca BT hizmet sağlayıcılarının geniş havuzundan ihtiyaç duyduğu hizmetlere ve kaynaklara erişim sağlamaktadır. Daha düşük maliyet daha fazla esneklik anlamına gelen bu erişimin doğasında, kısa vadeli kalkınma ihtiyaçlarını karşılayan ve gelecekte daha da önemi artacak olan sonuç odaklı sözleşmeler bulunmaktadır (Marco, 2019).

Öte yandan teknolojik gelişmeler ile dış kaynak kullanım ilişkisi, şirketlerin sanallaşması aşamasında da görülmektedir. Örneğin Slovenya'da turizm sektöründe yapılan bir araştırmaya göre; dış kaynak kullanımı şirketlerin sanallaşmasını, bilgi ve iletişim teknolojilerinden daha güçlü etkilemektedir. Çünkü bu yöntem şirketin bilgi ve birikim kazanmasını ve küresel anlamda rekabet gücünün daha fazla arttırmasını sağlamaktadır. Bu süreçte şirketler dış kaynak kullanımına başvururken temelde rekabet, organizasyon ve bilgi eğilimlerini dikkate almaktadırlar. Diğer bir ifade ile dış kaynak kullanımı şirketin; sanallaşmasının önünü açmakta, rekabet gücünü daha fazla arttırmakta ve daha fazla bilgi edinmesine yardımcı olmaktadır (Manzin ve Kodrič, 2009, s. 57). Ancak bu süreçte teknoloji odaklı dış kaynak kullanımının "bilgi sızıntısına" bağlı olarak bir takım sorunları da beraberinde getirdiği belirtilmektedir. Özellikle artan dış kaynak kullanımı ihtiyacının daha düşük 
maliyetli bir bölgede hayata geçirilmesi, düşük maliyetli bölgede faaliyet gösteren firmalar için bir yandan inovasyon temelli "yaparak öğrenmenin" önünü açarken diğer yandan bilgi sızıntısı sorununu ön plana çıkarmaktadır. Çekirdek faaliyetlerin dış kaynaktan sağlandığı ve yaşanan teknolojik gelişmelere karşı geleneksel yöntemlerin kullanıldığı ya da maruz kalındığı (bürokrasi, yasal zemin vb.) durumlarda benzer sorunlarla karşılaşmak daha olası hale gelmektedir (Yong, 2008, s.420).

\section{Küreselleşme ve Sanayisizleşmede Dış Kaynak Kullanımı}

Özellikle herhangi bir kurum ya da kuruluşun daha önce yaptığg işlerle ilgili faaliyetlerini para karşılığı başkasına aktarması çerçevesinde şekillenen dış kaynak kullanımı, küreselleşme sürecinin önemli bir uzantısı olma niteliği taşımaktadır (Ritzer, 2011, s.244). Buna göre büyük ve hantal işletmelerin ortadan kalkması, sürekli farklılaşan tüketici taleplerinin karşılanması, rekabetin gerektirdiği ucuz ve kaliteli üretim yapılabilecek esnekliğin sağlanması, yalın ve tam zamanında üretim, rekabet avantajını sağlamak adına küçülme, dış kaynak kullanımını şekillendiren temel etkenlerin başında gelmektedir (Dereli, 2001). Bu yönüyle küresel anlamda dış kaynak kullanımı işletmelere önemli hatta tahmin ettiğimizden çok daha fazla yararlar sağlamaktadır. Örneğin yerel bir çalışan için gerekli olan genel masraflardan kurtulma, işe alma ile basit çalışma ekibinde oluşacak olan karmaşıklığı önleme, işleri basit ancak maksimum üretkenlikle gördürme gibi amaçlar bu süreçte belirgin rol oynamaktadır. Buna göre geleneksel yaklaşımlarda sadece bütçe maliyetlerini azaltma stratejisi olarak kullanılan dış kaynak kullanımı, günümüzde işletme sahiplerinin inovasyon ve iş verimliliğinin arttırılmasında da önemli bir araç olarak kullanılmaktadır. Bu nedenle küreselleşme sürecinde dış kaynak kullanımı, işletmelerce daha esnek, daha rekabetçi dolayısıyla oldukça çekici bulunmaktadır (Leshchenko, 2018). Küreselleşmeye bağlı olarak ağı daha da genişleyen bu tür üretim ilişkileri günümüzde "küresel dış kaynak kullanımı" (global outsourcing) ifadesi ile de anılmaktadır. Bu gelişme bilinen maliyet, verimlilik ve çekirdek faaliyetlere odaklanma sürecinde yaşanacak avantajların yanı sıra profesyonel ve aranan yeteneklerde insan kaynağ sağlama amacına da önemli oranda katkı sağlamaktadır (Babu, 2018).

Öte yandan küresel dış kaynak kullanımında sanayisizleşme süreci iki farklı şekilde yorumlanmaktadır. Bunlardan birincisi günümüzde ve gelecekte dış 
kaynak kullanımının sanayi sektöründen çok hizmet sektöründe yaygınlaşması ve yaygınlaşmasının öngörülmesidir. Diğeri ise söz konusu ülkenin kendi sınırları içinde değil de başka bir ülkede faaliyet göstermesi, yatırım yapması ya da ihtiyaç duyduğu mal veya hizmeti ithal etmesi şeklinde yorumlanmaktadır (Wood, 2018). Bu kapsamda örneğin dünyanın dört bir yanındaki işletmelerin, hükümetlerin ve kurumların karşılaştığı stratejik ve operasyonel CEO-gündem konularına odaklanan bir Amerikan küresel "yönetim danışmanlık" şirketi olan (Erişim Tarihi: 10 Temmuz 2019, https://en.wikipedia.org/wiki/A.T._Kearney) ATKearney; 2016 yılı için finansal, insan becerileri ve kullanılabilirliği ve iş ortamına göre en iyi 10 dış kaynak noktalarını şu şekilde sıralamıştır: Hindistan, Çin, Malezya, Brezilya, Endonezya, Tayland, Filipinler, Meksika, Şili. Bu kapsamda ATKearney, iş süreçlerini otomatikleştirmeye ve standartlaştırmaya yardımcı olan yazılımlar ile özellikle Hindistan ve Çin'de uzun süredir hizmet veren ve dünya çapında faaliyet gösteren tedarikçilere bir anlamda alternatifler sunmaktadir (Vollmer, 2016).

\section{İşlerin Yeniden Yapılandırılmasında, Eşitsizlik ve Sosyal Korumada Dış Kaynak Kullanımı}

Küresel anlamda dış kaynak kullanımının genişlemesi sürecinde özellikle neo-liberallerin sıkça başvurduğu konulardan birisini Joseph Schumpeter' in "yaratıcı yıkım” teorisi oluşturmaktadır. Bu yönüyle küresel anlamda dış kaynak kullanımının büyük ölçüde ya da bütünüyle yıkıcı yönleri bulunmaktadır. Örneğin ABD açısından dış kaynak kullanmak; iş imkânı kaybının, iş imkânlarının ve sanayilerinin içlerinin boşaltılmasının ya da tamamen tahrip edilmesinin, askeriye, sağlık sistemi, çocuk ve yaşlı bakımı gibi birçok işin içinin boşaltılmasının diğer bir ifade ile sistemin bağırsaklarının dışarıya çıkmasının önünü açmaktadır. Dış kaynak kullanan ülke açısından "yıkım” olarak değerlendirilen bu durum, dış kaynak sunan ülke açısından yeni iş imkânlarını tetikleyen "yaratıcılık” boyutunu oluşturmaktadır (Ritzer, 2011, s.246). Örneğin 1990'larda tekstil imalatının Çin, Hindistan ve Meksika gibi düşük ücretli ülkelere kayması Amerikan tekstil endüstrisini önemli ölçüde etkilemiştir. 1990-2012 yılları arasında Amerikan yurtiçi tekstil sektörünün 3/4’ü düzeyinde olan 1,2 milyon çalışan işinden olmuştur (Ford, 2018, ss.26-27). Bu durum işsizlik ve türevi sosyal politika sorunlarının yaygınlaşması açısından da büyük önem taşımaktadır. 
Öte yandan küresel işgücü piyasalarında vasıflı çalışanlar lehine önemli şartlar sunan teknolojik gelişmeler kutuplaşma temelli eşitsiz bir toplum modelinin ortaya çıkmasında (Erdut, 1998, ss.148-149) önemli bir etkiye sahiptir. Temel nedenleri arasında; rutin işlerin otomasyonu, istihdam politikalarının ticaret vasıtası ile uluslararası entegrasyonu ve işletmelerin üretimlerini yurt dışına kaydırmaları gösterilen kutuplaşma sorununda; ekonomide orta düzey vasıf gerektiren sağlam orta sınıf işler yok olurken, onların yerini düşük ücretli hizmet işlerinin ve yüksek vasıf gerektiren profesyonel işlerin kombinasyonunun alması görülmektedir (Ford, 2018, ss.71-72). Aynı şekilde işlerin yeniden yapılandırılması, eşitsizlik ve sosyal koruma konuları kapsamında bir diğer önemli noktayı da cinsiyet ayrımı ve eğitim konuları oluşturmaktadır. Bu nedenle kadın istihdamının arttırılması, cinsiyet ayrımcılığının önlenmesi, istihdamda katılımın ve çeşitliliğin sağlanması konularına 2018 B20 Zirvesinde ayrıca dikkat çekilmiştir. Bu konuda G20 ülkelerinin 4/5'i cinsiyet ayrımcılığını yasaklayan kanunları kabul etmiş, yaklaşık yarısı ise "eşit işe eşit ücret" politikasını uygulamıştır. Endonezya ve Suudi Arabistan cinsiyet ve ücret konusunda ayrımcılık yapılmaması konusunda düzenleme yapmayan ülkeler arasında iken Arjantin, Avusturalya, Fransa, Güney Afrika, Türkiye, İngiltere gibi ülkeler bu konudaki düzenlemeleri kabul etmiş ve bunu ulusal çapta zorunlu k1lmışlardır (Buckley ve Diğerleri, 2018, s.26).

Buraya kadar yapılan açıklamalara bağlı olarak eşitsizlik sorununun yaygınlaşmasında "kutuplaşma" sorunu önemli bir paya sahiptir. Aynı şekilde; ulusal ve uluslararası gelişmelere bağlı olarak işgücü piyasalarının yeniden yapılandırılması, dış kaynak kullanımının "yaratıcı yıkım” etkisi, cinsiyet ayrımcılığı, eğitim sisteminde yaşanan diğer sorunlar temelde kutuplaşma sorununu besleyen sorunlar olarak görülmektedir. Ayrıca yaşanan bu tür sorunlar gerek ulusal gerek uluslararası boyutta sosyal koruma ihtiyacını her geçen gün arttırması açısından da büyük önem taşımaktadır.

\section{Demografik, Toplumsal ve Çevresel Değişimde Dış Kaynak Kullanımı}

Demografik anlamda dış kaynak kullanımının bir yönünü; mikro ölçekte küçük çocukların bakımını başkalarına veren ebeveynler, yaşlı kimselerin günlük bakımını yapan kurumlar ya da bakımevleri oluşturmaktadır. Bu kapsamda örneğin gelişmiş ülkelerde mikro düzeyde çocuk ya da yaşlıların bakımının çoğu zaman azgelişmiş ülkelerden gelen yasal ya da yasadışı göçmenlere fason yaptırılması, dış kaynak kullanımının demografik boyutunu 
oluşturmaktadır. Hatta anneliğin dahi dış kaynak kullanımı düzleminde ele alınması dahi söz konusu olabilmektedir. Bu noktada İsrail'deki çiftler için taşıyıcı annelik hizmeti veren Hintli kadınlar önemli bir örnek olarak karşımıza çıkmaktadır. Bu durum küresel anlamda çocuk ve yaşı bakımı hatta annelik hizmeti zincirinin önemli bir boyutunu oluşturmaktadır. Bu yönüyle demografik anlamda dış kaynak kullanımı ve boyutları ülkeler bazında; doğum oranları, çocuk sayısı, yaşlı sayısı, göçmenlik gibi pek çok konuyu kapsayan bir niteliğe sahiptir (Ritzer, 2011, s.244).

Öte yandan küresel işgücü piyasalarının değişiminde önemli bir konuyu da iklim değişikliği ve yeşil ekonomiye geçiş oluşturmaktadır. Buna göre gelecekte işgücü piyasalarında en önemli darboğazın ilgili sektörlerde gerekli olacak beceri ve yeteneklerde yaşanacağı belirtilmektedir. Örneğin sadece konut sektöründe 2050 yılına kadar 3,5 milyon yeni iş olacağı öngörülmektedir. Bu durum ekonomilerin yeşillenmesinde önemli bir problem olarak görüldügünden yeşillenmenin devamı için ilgili sektörlerde gerekli beceri ve yeteneklerin ortaya çıkarılması ve bu duruma uyan eğitim programlarının bugünden hayata geçirilmesi gereğini ön plana çıkarmaktadır. Örneğin Almanya'da 2007 yılında yapılan bir araştırma; şirketlerin özellikle bilgi yoğun mesleklerde kalifiye eleman sıkıntısı çektiğini ortaya koymuştur. Aynı şekilde İngiliz Endüstri Konfederasyonu yetkilileri yeşil alan sektörlerinin; tasarımcılar, mühendisler ve elektrikçiler de dâhil olmak üzere teknik uzman bulmakta zorlandıklarını belirtmiştir. ABD'de ise Ulusal Yenilenebilir Enerji Laboratuvarı enerji tasarrufuna dikkate çekerek israfın, büyümenin önünde önemli bir engel olduğunu dile getirmiş ve bu konuda bilgi, beceri ve eğitim açı̆̆ının önemini vurgulamıştır. Brezilya'da ise yüksek vasıflı personel kıtlığının ekonomik gelişmede önemli bir problem olduğu belirtilmiş ayrıca bu süreçte biyoyakıt rafinelerinin önemi vurgulanmıştır (ILO, 2010, s.13).

\section{Yeni Nesil Dış Kaynak Kullanımının İşgücü Piyasalarının Geleceği Üzerinde Olası Etkileri}

Yeni nesil dış kaynak kullanımının işgücü piyasalarının geleceği üzerinde olası etkilerini istihdam ve ücret ilişkileri açısından değerlendirmek mümkündür. $\mathrm{Bu}$ etkilerin ulusal düzeyden çok küresel anlamda daha geniş bir çerçevede gerçekleşmesi, konunun daha çok ülkeler bazında uluslararası değerlendirilmesi gereğini ön plana çıkarmaktadır. 


\section{İstihdam İlişkilerine Olası Etkileri}

Uzun süredir el emeğine dayanan (mavi yakalı) imalat sektöründe görülen dış kaynak kullanımı, günümüzde üst düzey beceri isteyen ve çoğunlukla beyaz yakalıları kapsayacak boyutta küresel anlamda bir genişleme göstermektedir. Bilişim teknolojileri başta olmak üzere hukuk, muhasebe, mimari, gazetecilik, tıp vb. işler bu kapsamda büyük önem taşımaktadır (Ritzer, 2011, s.245). Dolaysıyla işletme yönetimlerinin karşılaştı̆̆1 en önemli sorunlardan birini farklı çalışma gruplarının gerekli vasıf ve bilgi düzeylerine eriştirilmesi ve bunun için gerekli eğitimlerin sağlanması oluşturmaktadır. Bu eğitim, teknolojik değişmelerin gerektirdiği uzmanlık bilgilerini sağlama ve süreklilik arz eden vasıf ve beceri yetersizliklerini kısa dönemde giderme çabalarına bağlı olarak şekillenmektedir (Dereli, 2001). Bu durum diş kaynak hizmeti sunan şirketler hatta bu pozisyonda olan ülkeler için ayrıca önem taşımaktadır.

Nitekim 2001 yılında yapılan bir araştırma; teknolojik gelişmelerin işgücü kompozisyonundaki değişimler üzerinde yüksek eğitimli işçiler lehine, ticaret ve dış kaynak kullanımından daha güçlü bir etkisinin olduğunu ortaya koymaktadır. Diğer bir ifade ile bilgisayarlara ve Ar-ge'ye yapılan yatırımlar eş zamanlı olarak yüksek eğitimli olan işgücüne özellikle bazı üniversitelerde potansiyel çalışan konumunda olan bireylere olan talebi arttırmaktadır. Yine aynı araştırmaya göre firmaların dış kaynak kullanımını yaygınlaştıracak faaliyetlere yönelmesi tüm eğitim seviyeleri üzerinde negatif bir etkiye sahip iken düşük eğitimli bireylerde bu etkinin oldukça güçlü olduğu ifade edilmektedir. Diğer bir ifade ile bu noktada özellikle dış kaynak kullanımının üniversite mezunu olmayan işgücü üzerindeki olumsuz etkileri oldukça belirgindir. $\mathrm{Bu}$ etki nispeten üniversite mezunu olan eğitimli işgücüne talebi arttırması noktasında oldukça olumludur denilmiştir (Paul ve Siegel, 2001, ss. 259-261). Nitekim ILO, 2008 yılındaki 97. Oturumunda özellikle beceri geliştirmeye odaklanmış ve bu kapsamda bütünsel bir yaklaşım ortaya koymuştur (ILO, 2010, ss.18-19). Buna göre dış kaynak kullanımının istihdam ilişkileri üzerinde beklenilen en büyük etkisi vasıflı işgücüne olan talebi daha da arttıracağ yönündedir. Ayrıca bu noktada yaşanılan gelişmelerin gerek ulusal gerek uluslararası işgücü piyasalarında eğitim ve beceri geliştirme ihtiyacını daha da tetikleyeceği beklenilen bir olgudur.

Bu kapsamda Hindistan günümüzde küresel anlamda en iyi yetenekli işgücü yeteneğini bünyesinde barındıran ve özellikle gelişmiş ekonomilere bu kapsamda 
hizmet sunan deniz aşırı ülke niteliği taşımaktadır. Aynı şekilde dış kaynak sağlama konusunda Çin'de ise özellikle; PC tabanlı uygulama geliştirme, kalite güvence testi, sistem entegrasyonu, veri işleme ve ürün geliştirme gibi konularda küresel projeler çekmektedir. Bahsedilen konularda Hindistan'ın bile Çin'den bu konuda dış kaynak sağladığı dikkat çekilmektedir. Ayrıca Çin'in alt yapıya, İngilizce dil eğitimine ve internet bağlantısı kullanılabilirliğe önemli yatırımlar yapması diş kaynak konusunda önemli avantajlar sağlamaktadır. Aynı şekilde önemli boyutta bir telekomünikasyon yelpazesini başarması, y1llık ortalama 400 bin üniversite mezunu ile küresel üretim sürecine dâhil olması ve ABD'li şirketler ile birlikte çalışması bu noktada büyük önem taşımaktadır. Öte yandan; internet programlama, web tasarımı, web sunucusu, web veri tabanı gibi konularda uygulama geliştirme yapan Rusya da kişi başına en fazla mühendis ve bilim adamının düştügü üçüncü ülke konumundadır. Benzer şekilde iyi eğitimli, deneyimli, İngilizce yetkinlikli, orta ve üst düzey yöneticilik yeteneği bulunan ve müşterilerle direkt iletişim kurma becerisine sahip bir işgücü kitlesi bulunmaktadır. Doğu Avrupa'da ise Belarus, Bulgaristan, Çekya Macaristan, Polonya, Romanya, Ukrayna gibi ülkeler özellikle karmaşık bilimsel projeler ve ticari tasarımlar için uygulama geliştirme konularında uzmanlaşmışlardır. Aynı şekilde bölgenin nitelikli bilim insanları ve mühendisler yetiştiren sağlam bir eğitim tabanına sahip olması dış kaynak sunumu konusunda bölgeyi avantaj1ı k1lmaktadır. Latin Amerika'da Arjantin, Brezilya, Meksika gibi ülkelerde de web programlama ve uygulama geliştirme konularında uzmanlaşılmıştır. Özellikle bu ülkelerin ABD ile aynı saat diliminde olmaları zamana duyarlı programların oluşturulmasında ve hayata geçirilmesinde büyük önem taşımaktadır. Hızlı ve düzenli iletişimin bölgede zamanla gelişmesi de bu konuda etkin rol oynamaktadır (Leavitt, 2007).

Öte yandan Filipinler'de İngilizce konuşan geniş bir nüfusun olması, niş pazarlarına uygun çağrı merkezlerinin yer alması, okuryazarlık oranının giderek yükselmesi, iyi bir telekomünikasyon alt yapısının olması, işgücünün nispeten ucuz olması dış kaynak sunumunda ülkeyi ayrıca avantajlı kılmaktadır. Aynı şekilde İrlanda'nın BT teknolojilerine sahip olmasının yanı sıra yazılım geliştirme ve test etme konusunda İsrail' in ise ticari yazılım geliştirme, güvenlik ve antivirüs yazılımları geliştirme konusunda gelişmiş olması küresel dış kaynak sunumu konusunda büyük önem taşımaktadır. Bu kapsamda iyi eğitim görmüş, yabancı dil bilgisi yüksek, yazılım, BT, veri geliştirme, işleme vb. konularında gelişmiş yetenekler, iyi yönetici vasıfları taşıyan işgücü bu değişim sürecinde 
daha fazla talep görmektedir. Örneğin BT açısından ABD ve Avrupa' da 2006 yılında \%20 olan yazılım konulu dış kaynak kullanımı 2009'da \%28'e yükselmiştir. Aynı zamanda yurtdışı yazılım geliştiricilerinin sayısı ise 2006'da 360 bin civarında iken 2009' da 1 milyonu bulmuştur. Bu süreçte mobil teknoloji kullanımının hızla artmasına bağlı olarak karmaşıklığın ve güvenlik sorunlarının artması sürecin şekillenmesinde önemli bir faktör olarak dile getirilmektedir (Leavitt, 2007).

Buna göre çalışma ilişkileri açısından dış kaynak kullanımının niteliğgini değiştiren en önemli etken teknoloji ve bilgi tabanlı ekonomide yaşanan gelişmelerdir. Çoğunlukla teknoloji ve bilgi tabanlı ekonomideki gelişmelere bağlı olarak tanımlanan bu süreç çalışma ilişkileri açısından da vasıflı işgücü merkezinde şekillenmektedir. Dış kaynak kullanımının değişen bu niteliği çalışma ilişkileri açısından değerlendirildiğinde şu özellikler göze çarpmaktadır (Tablo 3).

Tablo 3

Dış Kaynak Kullanımının Çalışma Yöntemleri Üzerindeki Etkileri

\begin{tabular}{|c|c|c|}
\hline Geleneksel & Günümüz & Gelecek \\
\hline İş güvencesi & Kariyer esnekliği & $\begin{array}{l}\text { Dinamik istihdam } \\
\text { edilebilirlik }\end{array}$ \\
\hline $\begin{array}{l}\text { Şirkete ait kurumsal kariyer } \\
\text { yapıs1 }\end{array}$ & $\begin{array}{c}\text { Kendi kendine sorumlu kariyer } \\
\text { portföyü }\end{array}$ & Gig (paylaşım) ekonomi \\
\hline Kuruma bağlılık & Ağ portföyüne bağl1lık & Kendine bağl1lık \\
\hline $\begin{array}{l}\text { Organizasyon odakl1 } \\
\text { performans anlayış1 }\end{array}$ & Esnek proje tabanlı performans & $\begin{array}{l}\text { Bireysel çaba odaklı } \\
\text { performans }\end{array}$ \\
\hline $\begin{array}{l}\text { Organizasyon eğitim } \\
\text { ihtiyaçlarını değerlendirir }\end{array}$ & $\begin{array}{c}\text { Organizasyon, ihtiyaçları } \\
\text { değerlendirmek için araçlar sağlar }\end{array}$ & $\begin{array}{l}\text { Birey ihtiyaçlarını kendisi } \\
\text { belirler ve gerekli araçları } \\
\text { kendisi sağlar }\end{array}$ \\
\hline $\begin{array}{c}\text { Eğitim ve gelişim } \\
\text { olanaklarını organizasyon } \\
\text { sağlar }\end{array}$ & $\begin{array}{l}\text { Çalışanlar bireyselde rekabetçi } \\
\text { kalabilmek için yeteneklerini } \\
\text { geliștirmek zorundadırlar }\end{array}$ & $\begin{array}{l}\text { Birey ve organizasyon } \\
\text { beceri geliştirme sürecinde } \\
\text { birlikte çalıșrlar }\end{array}$ \\
\hline
\end{tabular}

Kaynak: Lepeak, 2018.

Tabloya göre geleneksel dış kaynak kullanımında; iş güvencesi, kurumsal kariyer, kuruma bağl1lık, organizasyon odaklı performans, organizasyonun ihtiyaçları doğrultusunda eğitim, eğitim ve gelişim olanaklarının organizasyon tarafından sağlanması özellikleri göze çarpmaktadır. Günümüz dış kaynak kullanımında ise; kariyer esnekliği, kendi kendine sorumlu kariyer anlayışı, ağ portföyüne bağl1lık, esnek tabanlı performans, organizasyonun ihtiyaçları doğrultusunda araçlar sağlaması, yetenekleri geliştirme zorunluluğu konuları ön plana çıkmaktadır. Yakın bir gelecekte ise dış kaynak kullanımın istihdam 
ilişkilerine etkisinin; öncelikle dinamik istihdam edilebilirlik boyutunda, gig (paylaşım) ekonomisi çerçevesinde, kariyer konusunda kendine bağlılık kapsamında, bireysel performans odaklı, bireyin eğitim ve geliştirme ihtiyaçlarını kendisinin belirlediği ve bu süreçte organizasyon ile birlikte çalıştığı bir ortamda şekilleneceği öngörülmektedir.

Bu kapsamda dış kaynak kullanımının değişen bu niteliğinin çalışanlar üzerinde özellikle 2020 yılına doğru yıkıcı bir güç haline geldiği belirtilmekte, ayrıca bunun sonraki yıllarda da devam edeceği tahmin edilmektedir. $\mathrm{Bu}$ sorunun ortaya çıkması daha çok teknolojik gelişmelere bağlı olarak çalışanların daha fazla yer değiştirmesine bağlanmaktadır. Ayrıca serbest yetenek üzerine kurulu daha dinamik bir ekonomik işleyişi tetikleyen bu dönüşümün, geleneksel iş ve istihdam anlayışını da önemli derecede etkileyeceği öngörülmektedir. $\mathrm{Bu}$ etkilerden bazılarının şu şekilde gerçekleşeceği tahmin edilmektedir (ISS, 2016, s.39):

- Daha fazla çalışan, bağımsız çalışma ve kişisel gelişim arzusundan etkilenecek ve istihdam sürecinde işveren, daha fazla şart öne sürecektir,

- Çalışanlar ihtiyaç duyulmadan önce yeni beceriler kazanma konusunda ustalaşmak zorunda kalacaklardır,

- Ortaya çıkan serbest ekonomide egemen istihdam modeli paralı entelektüeller (intellectual mercenaries) olarak çalışan kişilerin oluşturduğu ağlar ve ekosistemler olacaktır. Bu açıdan iş yapma; daha işbirlikçi, daha şeffaf ve daha teknoloji etkin gerçekleşerek hızlı bir döngüde gerçekleşecektir,

- Belirli bir kariyere bağlı farklı sorumluluklar dizisi ve buna bağlı kariyer esnekliğine duyulan ihtiyaç, dinamik işe alınabilirlik, çeşitli rollere uygulanabilecek beceri ve yeterliliklere hızlı geçiş her geçen gün daha da önem kazanacaktır,

- İşletmeler için paralı entelektüeller rekabetin ana faktörü olacağından bunu elde etmek için küresel rekabet ön plana çıkacaktır ve küresel insan kaynakları havuzlarına daha fazla önem verilecektir,

- Esnek iş düzenlemeleri giderek yaygınlaşacak, tam zamanlı çalışan gruplarından sözleşmeyle serbest çalışanların yeteneklerine daha fazla başvurulacaktır. Yine bu süreçte markaların önemi ön plana çıkacaktır, 
- İşletmeler hızlı bir şekilde bir araya getirebilecekleri ve yeniden yapılandırabilecekleri yetenek havuzlarını ve sistemlerini tercih edeceklerinden bireyler, rolden role özgürce ve örgütsel sınırların olmadığı bir işgücü piyasasında yer alacaklar ve daha mobil davranacaklardır,

- İş dünyasının liderleri ve müşterileri çeviklik, ölçülebilirlik ve talepler için gerekli yetenekler üzerinde yoğunlaşacaklardır. Hızlı bir şekilde eskiyen bu özellikler sebebiyle sürekli önde olabilmek için her zaman yeni yeterlilikler üzerinde durulacaktır,

- Bireyler istihdam edilebilirliğini arttırmak için becerilerini geliştirme amacıyla izin süreleri de dâhil zamanlarının büyük bir kısmını kendilerini geliştirmeye ayıracaklardır,

- Öğrenmenin; gelecekte bir zamanda ihtiyaç duyabileceğimiz her türlü bilgi ve beceri için öğrenme, tam zamanında öğrenme, yaklaşan bir görev için öğrenme, kullanacak bir araç için öğrenme gibi çok farklı boyutları ortaya çıkacaktır.

Buna göre niteliği değişen dış kaynak kullanımının gelecekte işgücü piyasasına etkileri; bağımsız çalışma, işgücü istihdamı için daha fazla şart, ihtiyaç duyulmadan önce beceri kazanma, ağlar, ekosistemler, beceri ve yetkinliklere hızlı geçiş, paralı entelektüeller, küresel insan kaynakları havuzları, daha esnek ve daha bireysel iş ilişkileri, daha mobil işgücü piyasası, kendini geliştirme konusunda daha fazla zamana ihtiyaç duyma, tam zamanında öğrenme başta olmak üzere farklı boyutlarda ve türlerde öğrenme şekillerini kapsayan geniş bir yelpazede gerçekleşeceği tahmin edilmektedir.

\section{Ücretlendirme Sürecine Olası Etkileri}

1993-1998 yılları arası Birleşik Krallık verileri dikkate alınarak uluslararası dış kaynak kullanımının ücret eşitsizlikleri üzerindeki etkilerinin ele alındığg 2006 yılında yapılan bir araştırmaya göre; teknolojik değişimler ücret eşitsizliğindeki artışın arkasındaki baskın gücü oluşturmaktadır. Yine aynı araştırmada teknolojik gelişmelere bağlı aynı dönemde yaygınlaşan uluslararası dış kaynak kullanımının da ücret eşitsizlikleri üzerinde önemli rol oynadığı belirtilmiştir. Diğer bir ifade ile ücret eşitsizliğinin artmasında teknolojik değişimin faktör yanlılığı sektör yanlılığından daha büyük, uluslararası dış kaynak kullanımının ise sektör yanlılığından daha büyük bir etkiye sahiptir. 
Aynı araştırmaya göre 90’lı yıllarda İngiltere'de ücret eşitsizliğinin artması temelde beceriye dayalı işgücüne olan talebin artmasına bağlıdır. Bu durum vasıfl1-vasıfsz işgücü arasındaki uçurumu arttırır bir nitelik taşımaktadır. Ayrıca uluslararası dış kaynak kullanımı ücret eşitsizliğinin en önemli nedenleri arasında gösterilmektedir (Hijzen, 2007, ss.188-202).

Aynı şekilde 2013 yılında ABD'de yapılan bir araştırmaya göre dış kaynak kullanımı; gelişmiş ülkeleri, zaman içinde istihdam ve ücretler açısından olumsuz yönde etkilemiştir. Hatta bu durum söz konusu ülkeler için işgücü piyasasında istihdam ve ücret eşitsizliği ile eşanlamlı hale gelmiştir. Yine bu kapsamda 2000-2010 yılları arasında dış kaynak kullanımı, uluslararası işgücü piyasalarında olağanüstü değişikliklere yol açmıştır. Örneğin ABD' de aynı dönemde; bilgisayar ve elektronik endüstrisinde 407 bin, tekstil ve hazır giyim sektöründe 284 bin açık iş kaybı yaşanmıştır. Buna karşılık ulaştırma ve teçhizat endüstrisinde 95 bin, makine ve metal endüstrisinde ise 71 bin yeni iş ortaya çıkmıştır. Bu durum dış kaynak kullanımının istihdam sürecine etkileri açısından tam bir belirsizlik şeklinde yorumlanabildiği gibi kayıp işler ile yeni ortaya çıkan işler açısından kıyaslandığında negatif etkilerinin daha çok olduğunu ortaya koymaktadır. $\mathrm{Bu}$ kapsamda dış kaynak kullanımı vasıfsız işgücünün esnekliğini arttırmakta daha düşük vasıflı işgücünün talebinde ve ücretlerinde önemli düşüşlere yol açmaktadır. Yüksek ve orta vasıflı işgücü talebinde artış yaşanmakta ve bu durum verimlilik artışı ve ek masrafların azalması şeklinde yansımaktadır. Diğer bir ifade ile dış kaynak kullanımı ücret eşitsizliğini arttırmaktadır. Bu etki düşük vasıflı işçilerde negatif, orta vasıflı işçilerde önemsiz, yüksek vasıflı işçilerde pozitif yönlüdür (Keilani, 2013, ss.24-26).

İstihdam ilişkilerinden bağımsız olarak değerlendirilemeyecek olan ücret ilişkileri, niteliği değişen dış kaynak kullanımında önemli bir problem olarak karşımıza çıkmaktadır. Nitekim dış kaynak kullanımının niteliğinin değişmesinde teknoloji ve bilgi tabanlı ekonomide yaşanan gelişmelerin daha çok etkili olduğu dikkate alındığında genellikle vasıflı işgücü lehine değişen iş ilişkileri, ücret eşitsizlikleri konusunda önemli problemlere yol açabilmektedir. Kutuplaşma sorunu çerçevesinde dış kaynak kullanan bir ülke için yaratıcı yıkım etkisinin işgücü piyasası açısından daha çok yıkım yönlü etkilerinin ön plana çıtı̆̆ı görülmektedir. Bu kapsamda dış kaynak kullanımı küresel iş ilişkileri açısından her ne kadar zorunlu ve gerekli bir sistemi ifade etse de istihdam ve ücret ilişkileri açısından önemli problemlere yol açabilmektedir. 


\section{Genel Değerlendirme ve Sonuç}

Dış kaynak kullanımı tarihsel gelişim sürecinde olduğu gibi günümüzde de üretim sistemlerinin önemli bir boyutunu oluşturmaktadır. Küreselleşme süreci ile farklı bir boyuta taşınan bu sistem; 90'l y yllarda idari işlerin dış kaynağa verilmesi, yine 90'lı yılların ortalarında gelişmekte olan ülkelerde görülen bir dizi ekonomik kriz ve 2000'li yılların başından itibaren yaşanan hızlı teknolojik gelişmeler ile önemli bir dönüşüm sürecine girmiştir. Buna bağlı olarak ILO'nun çalışma yaşamının geleceğine yön vereceğini tahmin ettiği temel faktörler, dış kaynak kullanımının da niteliğini değiştirmekte dolaysıyla çalışma yaşamını yakından etkilemektedir.

2018 y1lı ILO komisyon raporunda çalışma hayatının geleceğini etkileyecek temel faktörler belirlenmiştir. Buna göre teknolojik değişim ve bilgi tabanlı ekonomi faktörü kapsamında; teknolojik gelişmeler arttıkça ve bilgi tabanlı ekonomiye yatırım yapıldıkça dış kaynak kullanımı daha cazip bulunmaktadır. Bu süreçte; hızlı teknolojik değişime bağlı olarak zaman kısıtlılığının yaşanması etkili olurken, hızlı dijitalleşme, bilgi teknolojileri ortaklarına yönelme, yapay zekâ, güvenlik açığı, akıllı otomasyon teknolojileri, yeni hizmet dağıtım modelleri, sanallaşma, bilgi sızıntısı konuları etkili olmaktadır. Küreselleşme ve sanayisizleşme kapsamında; küresel dış kaynak kullanım ağlarının sıklaşmasına bağlı olarak dış kaynak kullanımının küreselleşme sürecinin önemli boyutu haline gelmesi, sanayisizleşme boyutunda ise dışa yatırım yapılması ve hizmet sektörünün ağırlık kazanması etkili olmaktadır. İşlerin yeniden yapılandırılmasının eşitsizlik ve sosyal koruma üzerindeki etkilerinde; dış kaynak kullanımının doğasında bulunan yaratıcı yıkım etkisi, kutuplaşma sorunu ve eşitsizliğin artması dolayısıyla sosyal koruma ihtiyacının daha da artması etkili olmaktadır. Bunun yanında vasıflı işgücüne olan talebin artması ile cinsiyet ayrımı ve eğitim sisteminde yaşanan sorunlar da ön plana çıkmaktadır. Demografik ve çevresel etkenler kapsamında ise; yaşlı ve çocuk bakımının günlük bakım yapan kurumlar ya da bakımevlerine verilmesi veya bu sektörde yasal ya da yasadışı göçmenlerin çalıştırılması, taşıyıcı annelik hizmetinin sunulması, çevresel değişkenler bağlamında iklim değişikliği, yeşil ekonomiye geçiş politikaları ve yeşillenmeye bırakılan işler etkili olmaktadır.

Bu değişim sürecinin istihdam ilişkilerine etkisi ise; bağımsız çalışma, işgücü istihdamı için daha fazla şart, ihtiyaç duyulmadan önce beceri kazanma, ağlar, ekosistemler, beceri ve yetkinliklere hızlı geçiş, paralı entelektüeller, küresel 
insan kaynakları havuzları, daha esnek ve daha bireysel iş ilişkileri, daha mobil işgücü piyasası, kendini geliştirme konusunda daha fazla zamana ihtiyaç duyma, tam zamanında öğrenme başta olmak üzere farklı boyutlarda ve çok sayıda seçeneğin yer aldığ öğrenme türlerini kapsayan geniş bir çerçevede gerçekleşmektedir. Ayrıca bu dönüşüm sürecinde teknoloji ve bilgi tabanlı ekonomide yaşanan gelişmelerin daha çok etkili olduğu dikkate alındığında genellikle vasıflı işgücü lehine değişen iş ilişkileri, ücret eşitsizlikleri konusunda da önemli problemlere yol açabilmektedir.

$\mathrm{Bu}$ kapsamda yakın bir gelecekte küresel işgücü piyasaları açısından teknoloji ve bilgi tabanlı ekonomi doğrultusunda vasıflı işgücüne odaklanan ülkelerin dış kaynak sunumu konusunda önem kazanacağ 1 beklenmektedir. Nitekim Hindistan'ının yanı sıra Çin'in bu konuda rekabet sürecine katılması ve aynı zamanda bazı gelişmekte olan ülkelerin alternatif dış kaynak hizmeti sunma yarışına girmeleri, küresel işgücü piyasalarının şekillenmesi açısından büyük önem taşımaktadır. Buna göre ILO'nun çalışma yaşamının geleceği öngörüsünde niteliği değişen dış kaynak kullanımını ayrıca değerlendirmesi ve bu konuda ülke analizlerine ağırlık vermesi küresel işgücü politikaları açısından büyük önem taşımaktadır.

Öte yandan ILO'nun çalışma yaşamının geleceği girişiminin temellerini; “iş ve toplum", "herkes için insan onuruna yakışır iş", "iş ve üretim organizasyonu" ve "işin yönetişimi” " başl1kları oluşturmaktadır. Bu kapsamda ILO, dört ana başlığın ulus devletler tarafından "sosyal diyalog" yoluyla hayata geçirilmesini önermektedir. Nitekim bu durum girişimin en önemli aşamalarından birini oluşturan mektubun, ulus devletler başta olmak üzere aynı zamanda ulusal işverenlere, işveren kurum ve kuruluşlarına ve işçi örgütlerine gönderilmesi sürecinde açıkça gözlenmektedir. Diğer bir ifade ile çalışma hayatının geleceği öngörüsünde niteliği değişen dış kaynak kullanımının ücret ve istihdam ilişkilerine olası etkileri sonucunda karşılaşılabilecek sorunların çözümlenmesinde "sosyal diyalog” mekanizması önemli bir yöntem olarak görülmektedir.

Finansal Destek: Yazar bu çalışma için finansal destek almamıştır. 


\section{Kaynakça/References}

Babu, S. (2018). What is Global Outsorcing, Erişim Tarihi, 08 Temmuz 2019, https:// www.quora.com/What-is-global-outsourcing.

Bartel, A., Lach, S., Sicherman, N. (2008). Outsourcing and Technological Innovations: A Firm-Level Analysis, IZA Discussion Paper No:3334, Erişim Tarihi: 03 Haziran 2019, https://www.econstor.eu/bitstream/10419/34920/1/560201141.pdf.

Buckley P., Majumder R., Stiller J., Thorns M. (2018). Ten Years on: The G20 Employment Process- Successes, Challenges and Impacts, Deloitte Publication, B20, Arjentina 2018.

Bulajic, A., \& Domazet D. (2012). Globalization and outsourcing and off-shoring. Journal of Emerging Trends in Computing and Information Sciences, 3(9), 1321-1328.

CICOPA. (2018). Strategic Paper: The Future of Work, Where do Industrial and Service Cooperatives Stand, Erişim Tarihi: 05 Haziran 2019, http://www.cicopa.coop/wpcontent/uploads/2018/03/The-Future-of-Work.pdf

CSIS. (2018). Forging the Future of Jobs: A Conversation with Guy Ryder, Director General of the ILO, Erişim Tarihi: 15 Haziran 2019, https://www.csis.org/events/ forging-future-jobs-conversation-guy-ryder-director-general-ilo

Dereli, T. (2001). Teknolojik Değişmeler-Çalışma Ilişkileri ve Yeni Istihdam Türleri, Erişim Tarihi: 08 Ağustos 2019, https://www.isguc. org $/ \mathrm{p}=$ article $\& \mathrm{id}=62 \&$ cilt $=3 \&$ sayi $=2 \& y i l=2001$.

Devabit. (2018), The Future of IT outsourcing: 6 Trends for 2019, Erişim Tarihi: 05 Haziran 2019, https://devabit.com/blog/it-outsourcing-trends-2019/

Erdut, T. (1998). Yeni teknolojilerin iş ilişkileri üzerindeki etkisi. İzmir: Türk Ağır Sanayii ve Hizmet Sektörü Kamu İşverenleri Sendikası Yayınları.

Ford, M. (2018). Robotların yükselişi. Çeviren: Cem Duran. İstanbul: Kronik Kitap.

GSA. (2018). Outsourcing Works: The Public Perception of Outsourcing, Erişim Tarihi: 05 Haziran 2019, http://test.gsa-uk.com/uploads/attachments/ cjx3a5m3o0308njh7q80zg1tm-the-public-perception-of-outsourcing.pdf

Hijzen, A. (2007). International outsourcing, technological change and wage inequality. Review of International Economics, 15(1), 188-205. Erişim Tarihi: 05 Temmuz 2019, https:/www.business.com/articles/future-of-tech-outsourcing/

ILO. (2008). ILO Declaration on Social Justice for a Fair Globalization, Erişim Tarihi: 03 Ağustos 2019, https://www.ilo.org/wcmsp5/groups/public/---dgreports/---cabinet/ documents/genericdocument/wcms_371208.pdf

ILO, (2010). A Skilled Workforce for Strong, Sustainable and Balanced Growth, A G20 Training Strategy, ILO Published, Geneva.

ILO. (2013). World of Work, Erişim Tarihi: 15 Nisan 2019, https://www.ilo.org/wcmsp5/ groups/public/---dgreports/---dcomm/documents/publication/wcms_216068.pdf. 
ILO. (2015). The Future of Work Centenary Initiative, Erişim Tarihi: 24 Mart 2019, https:/www.ilo.org/wcmsp5/groups/public/@ed_norm/@relconf/documents/ meetingdocument/wcms_369026.pdf.

ILO. (2018a). Decent Work and the Sustainable Development Goals: A Guidebook on SDG Labor Market Indicators, Erişim Tarihi 24 Nisan 2019, https:/www.ilo.org/ wcmsp5/groups/public/---dgreports/---stat/documents/publication/wcms_647109.pdf.

ILO. (2018b). The Future of Work. Erişim Tarihi: 12 Haziran 2019, http://www.cicopa. coop/wp-content/uploads/2018/03/The-Future-of-Work.pdf.

ILO. (2016). Non-Standard Forms of Employment, A Feature of the Contemporary World of Work, Erişim Tarihi: 05 Haziran 2019, https://www.ilo.org/global/about-the-ilo/ newsroom/news/WCMS_534122/lang--en/index.htm

ILO. (2019). Work for A Brighter Future, Erişim tarihi: 25 Haziran 2019, https:// www.ilo.org/wcmsp5/groups/public/---dgreports/---cabinet/documents/publication/ wcms_662410.pdf

ISS. (2016). 2020 Vision: Future of Outsourcing and Perspectives for Facility Management, Erişim Tarihi: 05 Haziran 2019, file://C:/Users/hp/Downloads/2016_ISS\%202020\%20 Future\%20of\%20Outsourcing\%20and\%20Perspectives..._Case\%20Study.pdf

Kakabadse, N., \& Kakabadse, A. (2000). Outsourcing: A paradigm shift. Journal of Management Development, 19(8), 670-728.

Keilani, H. Z. (2013). Outsourcing Impact on Labor market, MSc International Business Economics, School of Arts and Social Sciences Department of Economics, City University, London.

Leavitt, N. (2007). The Changing World of Outsourcing, Erişim Tarihi: 05 Haziran 2019, https://ieeexplore.ieee.org/stamp/stamp.jsp?tp=\&arnumber $=4404801$

Lepeak, S. (2018). The Future of Outsourcing-From Traditional to Next Generation, Erişim Tarihi: 03 Mayıs 2019, https://www.nearshoreamericas.com/the-future-ofoutsourcing-from-traditional-to-next-generation/.

Leshchenko, D. (2018). How is Globalization Related to Outsourcing, Erişim Tarihi, 08 Temmuz 2019, https://www.quora.com/How-is-globalization-related-to-outsourcing

Manzin, M., Kodrič, B. (2009). The Influence of Outsourcing and Information and Communication Technology on Virtualization of the Company, Managing Global Transitions, Vol: 7, No: 1, ss.45-60.

Marco, I. (2019). The Future of Tech Outsourcing Partnerships, Erişim Tarihi, 08 Temmuz 2019, https://www.business.com/articles/future-of-tech-outsourcing/

Paul, J.M.C., \& Siegel, S. D., (2001). The impacts of technology, trade and outsourcing on employment and labor composition. The Scandinavian Journal of Economics, 103(2), 241-264.

Ray, K. (2017). The Future of Outsourcing: The Largest Economic Transformation Ever, Erişim Tarihi, 10 Mayıs 2019, https://fee.org/articles/the-future-of-outsourcing-thelargest-economic-transformation-ever/. 
Ritzer, G. (2011). Küresel Dünya. İstanbul: Ayrıntı Yayınları.

Schiederjans, M. J., Schiederjans, A. M., Schiederjans, D. G. (2005). Outsourcing and insourcing in an international context. London: M.E. Sharpe.

Schwab, K. (2018). Dördüncü sanayi devrimi. Çeviren: Zülfü Dicleli. İstanbul: Optimist Yayınevi.

Stephaine F. (2014). How technology has changed outsourcing, Erişim Tarihi: 05 Haziran 2019, https://impacthub.org/resources/blog/how-technology-has-changedoutsourcing-3/

Vollmer, S., (2016). How Technology is Changing Outsourcing, Erişim Tarihi: 10 Haziran 2019, https://www.fm-magazine.com/news/2016/jan/how-technology-is-changingoutsourcing-201613775.html .

Wood, D. (2018). What is Deindustrialization? Defination-Examples, Erişim tarihi: 05 Temmuz 2019, https://study.com/academy/lesson/what-is-deindustrializationdefinition-examples.html

Yong, Y. (2008). Technology Innovation and risks in Outsourcing, The 2008 International Conference on Risk Management\&Engineering Management, Erişim tarihi: 05 Temmuz 2019, https://ieeexplore.ieee.org/document/4673265

Erişim Tarihi: 04 Nisan 2019, https://www.ilo.org/wcmsp5/groups/public/---dgreports/--dcomm/documents/correspondence/wcms_446487.pdf

Erişim Tarihi: 05 Haziran 2019, https://www.ilo.org/global/topics/economic-and-socialdevelopment/globalization/lang--en/index.htm

Erişim Tarihi: 16 Haziran 2019, https://en.wikipedia.org/wiki/ISS_A/S

Erişim Tarihi: 25 Haziran 2019, https:/www.ilo.org/global/topics/future-of-work/ WCMS_446487/lang--en/index.htm

Erişim Tarihi: 10 Temmuz 2019, https:/www.ilo.org/global/topics/future-of-work/ WCMS_569528/lang--en/index.htm

Erişim Tarihi: 10 Temmuz 2019, https://en.wikipedia.org/wiki/A.T._Kearney

Erişim Tarihi: 19 Temmuz 2019, https://www.ilo.org/wcmsp5/groups/public/--dgreports/---dcomm/documents/correspondence/wcms_446487.pdf 